UNIVERSIDAD AUTONOMA METROPOLITANA

Unidad Iztapalapa

\author{
DIVISION DE CIENCIAS SOCIALES Y HUMANIDADES \\ POSGRADO EN CIENCIAS ANTROPOLOGICAS
}

\title{
Viajes nostálgicos al terruño imaginario \\ La reconstrucción de lugar y cultura local en la comunidad transnacional a través de las contiendas de imágenes
}

\author{
SHINJI HIRAI
}

TESINA DE MAESTRIA EN CIENCIAS ANTROPOLOGICAS

DIRECTOR: DR. FEDERICO BESSERER

ASESORES: DR. RAUL NIETO CALLEJA

DR. MARIO HUMBERTO RUZ

MÉXICO, D.F.

AGOSTO DEL 2002 


\section{Índice}

\section{Introducción}

Capitulo 1 Viaje en seguimientos de la imagen dentro del sistema mundial

-Cultura, espacio y sujeto de estudio

-Revisión teórica de los estudios de comunidades transnacionales

-Las negociaciones de la presencia en el terruño y los conflictos

-Metodología de segur la imagen

-Políticas de la nostalgia

-Apropiación cultural y resistencia a las imágenes en el turismo

- ¿El viaje imposible?

Capitulo 2 La comunidad transnacional jaleña

-Topografía de la comunidad transnacional jaleña

-Mapa del viaje al terruño

Capitulo 3 Nostalgia de la diáspora mexicana

-Nostalgia de los migrantes

-Circulación de objetos

-Organizaciones de los migrantes

-Políticas del Estado-nación estadounidense

-Políticas del origen

-Los medios de comunicación

-Nostalgia de la segunda generación

Capitulo 4 Reconstrucción del terruño

-Nostalgia de los nativos

-Fiestas

-Continuidad y discontinuidad de la tradición

Capitulo 5 Imagen rustíca

-Campo y ciudad

-Cultura ranchera 
-Actuar el papel de ranchero

Capitulo 6 Viaje sagrado

-Papel de la iglesia católica

-Sistema emocional del retorno

-El retorno como peregrinación

-Ritual y poder

Capitulo 7 Imagen de mujer jaleña

-Nostalgia masculina

-Nostalgia de las mujeres

-Negociación de la identidad de genero en el circulo de la serenata

Capitulo 8 La tierra a la que todos quieren volver: Cultura, identidad y origen

-Construcción de la cultura local y el terruño (Véase el anexo 1)

-Identidad viajera

- ¿Hacia dónde va la comunidad transnacional?: hacia un espacio multicultal 


\section{INTRODUCCIÓN}

En el verano de 2000, estaba preparando un recorrido a Jalostotitlán, un municipio en Los Altos de Jalisco, para iniciar una investigación sobre las redes familiares que los jaleños (gentilicio) han construido entre México y varios asentamientos en Estados Unidos a lo largo de su historia migratoria que se remonta a las primeras décadas del siglo XX. Antes de hacer ese recorrido antropológico, revisé algunos trabajos de los antropólogos que realizaron las investigaciones en el municipio entre los años setenta y la primera mitad de los noventa (Fábregas 1986; González de la Rocha y Escobar Latapí 1990; López Cortes1999).

Jalostotitlán es un municipio de Los Altos de Jalisco poblado por 28110 habitantes y se ubica en el centro de la región alteña. ${ }^{1}$ Fue fundado por los conquistadores a mediados del siglo XVI. Aunque antes de la llegada de los conquistadores hispanos este lugar era un pequeño pueblo indígena y tiene un nombre náhuatl, el antropólogo Andrés Fábregas, quien realizó las investigaciones etnográficas de los años setenta a los principios de los ochenta en esta región, lo caracteriza como un pueblo de cultura ranchera criolla (Fábregas op.cit.).

Sin embargo, López Cortes, quien hizo el trabajo de campo casi una década después, sostiene que Jalostotitlán ha pasado de ser una comunidad cuya vida estaba arraigada estrechamente a la religión católica y la cultura ranchera a otra urbana e industrial. También su etnografía informa que el pueblo se ha transformado en un lugar en el cual existen estilos de vida, comida, música, modo de vestir, mercancías, practicas religiosas y enfermedades sexuales y drogadicción derivados de Estados Unidos (López Cortes 1999:15, 75-81, 236). Este proceso de la penetración de los objetos, costumbres, modos de vida y problemas sociales derivados de dicho país en el municipio se ha fortalecido e intensificado por algunos cambios en la migración en las últimas dos décadas, sobre todo desde la segunda mitad de los años ochenta.

\footnotetext{
${ }^{1}$ INEGI. Tabulados Básicos Nacionales y por Entidad Federativa. Base de Datos y Tabulados de la Muestra Censal, XII Censo General de Población y Vivienda, 2000. México, 2001
} 
La ley Simpson-Rodino (IRCA) en 1986, que permitió la legalización de la residencia en Estados Unidos de 2300000 migrantes mexicanos, ha promovido un asentamiento más regular y permanente de mexicanos en ese país (Lozano Ascencio 1998). Como diversas comunidades en otras regiones de México, a partir de entonces la migración jaleña a Estados Unidos ha aumentado drásticamente por intentar entrar a la categoría de migrantes con papeles y buscar una mejor oportunidad económica en ese país, cuando México estaba en una crisis. Este flujo ha tendido a ser la migración familiar más que individual, de una forma más permanente (González de la Rocha y Escobar Latapí 1990). Además del aumento del número de los migrantes a Estados Unidos y su establecimiento en ese país, la legislación de la IRCA ha creado un contexto en que los migrantes puedan regresar a sus lugares de origen con más frecuencia y mayor seguridad. Después de la legislación de esta ley, para los mexicanos que radican en Estados Unidos con tarjeta de residente, ha sido más fácil regresar a sus localidades de origen para visitar a sus familiares, hacer negocios en México o disfrutar de las fiestas patronales (Espinosa 1999), ya que no necesitan preocuparse por el siguiente cruce de la frontera al salir de Estados Unidos. En este contexto, se ha generalizado el retorno masivo de los migrantes a sus lugares de origen en México. En el caso de los migrantes jaleños, a pesar de la migración familiar y el establecimiento de la vida en los nuevos asentamientos, la mayor parte de ellos regresa a su terruño en un año, temporalmente (González de la Rocha y Escobar Latapí 1990). La mayoría de aquellos que regresan temporalmente de Estados Unidos realiza su viaje a México durante la época de las fiestas en la cabecera municipal, para asistir al Carnaval que se celebra cuarenta días antes de la Semana Santa y las fiestas patronales en agosto.

A pesar de la dispersión geográfica de los originarios de Jalostotitlán en los procesos de la migración masiva a Estados Unidos, aquellos que han salido del lugar natal han mantenido los vínculos con los habitantes de su lugar de origen en México no sólo a través del retorno, sino también por medio de la circulación constante de dinero entre los asentamientos y su terruño. Hay flujo de dinero que envían al municipio los jaleños avecindados en Estados Unidos, por ejemplo, la 
suma de remesas alcanzaba aproximadamente un millón de dólares al año en los años ochenta (González de la Rocha y Escobar Latapí 1990:542).

También existe la "simultaneidad" en la comunicación entre los jaleños de distintas localidades entre ambos países por el uso de nuevas tecnologías (Smith 1995). Por ejemplo, una página en el Internet, que encontré cuando estaba "navegando" para sacar los datos básicos del viaje al pueblo, titulada con el nombre del municipio y creada por un grupo de jóvenes que viven en Jalostotitlán, tiene varios tipos de información acerca del pueblo: la historia de Jalostotitlán, su localización, el acceso al pueblo, fotos de las fiestas patronales y el Carnaval, el calendario de las fiestas, eventos, comentarios de los visitantes de esta página, etc. Esta página está dirigida, principalmente, a los jaleños de distintos lugares, y la mayoría de sus visitantes son de la segunda generación de los migrantes, o sea, sus hijos nacidos o crecidos en Estados Unidos y que actualmente viven fuera de Jalostotitlán. Según sus comentarios, entraron a este sitio cibernético desde distintos lugares de Estados Unidos: Anaheim, Escondido, Turlock, Oakland, San Diego, Oxnard, Fresno, Los Angeles, Oklahoma, San Francisco, California; Dallas, Texas; Chicago, Illinois; Nueva York, y varios lugares de México. A través de esta página los visitantes se comunican entre ellos, conocen a los demás jaleños que están en otros lugares y mandan saludos a sus familiares y amigos del lugar de origen y otras localidades en Estados Unidos por medio de los demás visitantes que conocieron.

Aunque ellos vivan fuera de Jalostotitlán, Los Altos y que sean de la segunda generación, se identifican como jaleños. Por ejemplo, al entrar en el sitio por primera vez, muchos de ellos escriben, "¡Hola, soy de Jalos!" (Jalos es la apócope de Jalostotitlán), y un joven de Anaheim escribió un comentario ingenioso: "Para mi, Anaheim es el segundo Jalos, y Escondido, CA. es el tercer Jalos".

En el contexto en que se mantiene la circulación constante de gente, dinero, mercancías e información entre múltiples lugares de ambos países y que la identidad jaleña se representa más allá de la frontera nacional, la comunidad jaleña no se constituye sólo por la localidad en Los Altos de Jalisco; ni únicamente 
por aquellas personas que se quedan en este lugar en México. Como apunta el comentario de un visitante de Internet, Anaheim, Escondido y otras localidades en Estados Unidos en donde se encuentran los originarios del pueblo también se incluyen en la comunidad. En este sentido, la comunidad jaleña se extiende más allá de los límites locales y nacionales: es una comunidad transnacional que se ha construido por la articulación del lugar de origen con múltiples sitios dispersos en México y Estados Unidos.

Después de haber leído esos textos antropológicos, me imaginaba que Jalostotitlán, Los Altos de Jalisco, era una comunidad urbana e industrializada y que era una tierra de migrantes, o sea, un lugar que ha enviado a muchos migrantes hacia el Norte y cuya vida se ha cambiado a través de la migración transnacional. Gracias a la página en el Internet, pude saber la fecha del inicio de las fiestas patronales en Jalostotitlán, la fecha en que muchos miembros de la comunidad jaleña transnacional que viven en otros lugares regresan a su lugar de origen. A mi pareció muy buena idea ir a este pueblo en esa temporada para entrevistarme con algunos migrantes que regresan temporalmente a su terruño. Así que, decidí viajar, y al día siguiente de encontrar la página de Jalos en el Internet partí para Jalisco en el autobús nocturno desde la terminal del Norte en la Ciudad de México.

Después de realizar un viaje de diez horas de la capital-GuadalajaraJalostotitlán en autobús, finalmente llegué a mi destino de recorrido antropológico. Desde la terminal de autobús en el municipio, fui directamente al edificio de la presidencia municipal para obtener la información sobre los hoteles cercanos, en uno de los cuales pensaba quedarme durante la estancia. Ahí fue donde una joven jaleña, que me atendió en una oficina de la presidencia municipal, me dio otro texto que me hizo cambiar mi lugar imaginario. El texto era un folleto de Jalostotitlán con una frase "La tierra a la que todos quieren volver". El folleto tiene las fotos de iglesias, el santuario y la plaza y la información sobre la ubicación del municipio, acceso, direcciones de hoteles y restaurantes, la iglesia de la Asunción y los eventos que se celebran en las fiestas patronales y el Carnaval. Leí el folleto con mucha atención para encontrar alguna información sobre la migración jaleña, 
ya que lo que esperaba de Jalos era este fenómeno. Pero, no encontré frase ni foto alguna que evocaran la imagen de un lugar que ha cambiado por la migración a Estados Unidos y la penetración de las costumbres, los modos de vida y las mercancías derivadas de Estados Unidos. Más bien, el folleto presenta Jalos como un "pueblo" que tiene estilo de vida ranchera, un paisaje rústico y como un lugar sagrado de la religión católica, como describió Jalos el antropólogo mexicano Andrés Fábregas en los ochenta. Durante mi estancia, aparte de este folleto, conseguí otros folletos y revistas sobre Jalos que se distribuían y vendían en los espacios públicos, pero tampoco encontré en ellos palabra alguna como migrante o migración, en los textos y los discursos de los conductores de eventos y del presidente municipal. Me preguntaba donde se habían ido todos aquellos migrantes.

Sin embargo, al caminar en las calles en el centro de la cabecera municipal para observar las escenas de las fiestas, era fácil encontrar varias marcas de la historia de migración y la presencia de los migrantes: las casas de cambio y los restaurantes en los cuales se sirven comidas rápidas norteamericanas y comida mexicana al estilo norteamericano; docenas de camionetas y carros con placas del estado de California y el de Texas y la gente que habla ingles -los signos de lo norteamericano. Estos signos que llegaron a Jalos a través de las conexiones transnacionales entre múltiples sitios formaban parte del paisaje de la ciudad de estilo colonial. Pero, lo que representan los eventos que se celebran, tales como los carros alegóricos y las peregrinaciones como rituales católicos, corridas de toro, no tiene nada que ver con estos signos. Más bien, los eventos y las ceremonias representan las imágenes de pueblo ranchero y lugar sagrado del catolicismo, tal como los folletos representan al lugar. El paisaje de Jalos que vi fue una mezcla o una coexistencia entre dos distintas imágenes del lugar: Jalostotitlán como un barrio mexicano en Estados Unidos y Jalostotitlán como un pueblo colonial, ranchero y religioso que había existido antes de la urbanización, la industrialización y la transnacionalización de la vida. Me surgieron varias preguntas: ¿Dónde estaba yo? Que tipo de lugar están reconstruyendo los jaleños? ¿Jalostotitlán es un pueblo o una ciudad? 
Pero, el deslumbramiento de mi viaje continuó. Al ver la escena en que los jaleños que regresaron de Estados Unidos compraban las playeras con el nombre de Jalostotitlán y la imagen de la iglesia de la Asunción y al tomar las fotos de las escenas de los carros alegóricos por la espalda de la gente que estaba grabándolas como yo, me pregunté: ¿No es turismo este viaje tanto para mi como para los jaleños que han regresado? Pero, esta pregunta me surgió otra cuestión más inquietante: ¿Cómo se puede entender el hecho de que la diáspora regresa a su hogar para hacer turismo?

El término diáspora, por lo general, se refiere a algunas categorías de personas: expatriados, refugiados, residentes extranjeros, inmigrantes y grupos étnicos minoritarios (Safran 1991:83). El gobierno mexicano también empieza a usar este término al referirse a los mexicanos que viven en los territorios extranjeros, sobre todo, en Estados Unidos (González Gutiérrez 1999). Para el teórico de los estudios diaspóricos Stuart Hall, la diáspora "no se refiere a aquellas tribus dispersas cuya identidad sólo puede obtenerse en relación con alguna patria sagrada adonde ellas deben regresar a toda costa" (1990:235). Hall niega la idea de retorno de la diáspora a su origen fijo. Según Safran, para las diásporas, el retorno al origen es un mito que se construye en relación entre la diáspora, el país anfitrión y el origen, pero este mito no provoca el retorno real de los miembros de la diáspora a su origen (Safran 1991:94). Pero, en el caso de la diáspora mexicana, el retorno ya no es un simple mito, sino un mito que se hace real. Obviamente, en el municipio Jalostotitlán, la presidencia municipal y los organizadores de las fiestas juegan un papel importante en nutrir el mito de origen y el de retorno de la diáspora jaleña a su terruño a través de la producción de imágenes del pueblo distinto al lugar que ha cambiado a través de los procesos de la urbanización, la industrialización y la transnacionalización. Aparentemente, este lugar se está reconstruyendo tal como era o al menos tal como "debió haber" sido antes de estos cambios, por la inscripción de nuevas imágenes en el lugar.

No obstante, aun queda una cuestión sobre la frase del folleto, "La tierra a la que todos quieren volver". Es obvio que aquellas personas que regresan de Estados Unidos son los principales visitantes que "vuelven" a Jalos en el sentido 
literal, pero, al tomar en cuenta el hecho de que los folletos, los textos y los discursos en los eventos no dicen claramente a quien están invitando a la ciudad semejante al pueblo de estas imágenes, a mi parecía que esta frase ocultaba una intención más. ¿Acaso este "todo" se refiere a alguien más? Si es así, ¿a quién despierta esta frase la nostalgia hacia su terruño, que está en reconstrucción por los nuevos símbolos?

Hoy en día, varias personas dejan sus hogares y hacen distintas formas de viaje que atraviesa las fronteras nacionales. Algunas de ellas las cruzan como migrantes, expatriadas, refugiadas, etc. y viven lejos de sus orígenes como diásporas. Otras lo hacen, temporalmente, en su tiempo de ocio como turistas. Sin embargo, en las últimas décadas ha surgido otro tipo de movimientos globales de gentes: el retorno de las diásporas a sus "hogares". Hay varios casos de este viaje: el viaje de los jóvenes chinos estadounidenses a China, el retorno de los migrantes puertorriqueños en Estados Unidos a Puerto Rico, el de las diásporas portuguesas a su origen, el de los migrantes filipinos a Filipinas, etc. Las diásporas regresan a sus hogares e incluso en el turismo. El viaje de los jaleños en Estados Unidos a Jalostotitlán que describí brevemente no es el único caso del retorno de la diáspora al origen como turista. Por ejemplo, la diáspora negra hace turismo a Ghana, Senegal y Gambia para visitar "Madre África" (Bruner 1996; Ebron 2000).

Esta tesis es una etnografía de este viaje: el retorno de la diáspora a su origen como turista. Por lo general, los turistas dejan su hogar temporalmente y viaja a lugares lejanos y distintos a su hogar. Pero este turismo es un poco complicado: Hacen turismo para "regresar" a su "hogar". ¿Qué tipo de encuentro de personas surge cuando el retorno al origen se convierte en el turismo? ¿Cómo cambian el lugar y la cultura local cuando la diáspora realiza su mito de retorno y llegan a su origen para satisfacer la nostalgia y encontrar un paisaje de su terruño imaginario en un lugar real? El objetivo de esta tesis es, pues, explorar los procesos de la reconstrucción del lugar de origen y la cultura local dentro de una comunidad transnacional a través del retorno de la diáspora mexicana en Estados Unidos a México. 
Debo aclarar que no he podido emplear una sola posición fija en este estudio. Es cierto que por ser un investigador japonés, había sentido cierta distancia con los jaleños. Al principio, algunos trataban de entenderme desde la relación que existe entre los mexicanos y los japoneses en California, otros, desde las imágenes sobre los asiáticos difundidas en México. Pero esto no implica que hubiese podido observarlos "objetivamente". Más bien, las experiencias familiares de desplazamiento entre Corea y Japón y mi relación estrecha con la comunidad japonesa y la coreana en la Ciudad de México forman parte del interés en este tema y del proceso mismo de elaboración de conocimiento sobre las personas y la comunidad transnacional. ¿Cuál lugar es mi terruño? ¿A cuál cultura pertenezco? ¿Cuál es mi identidad? ¿Cómo la represento? Estas cuestiones también habían surgido de mis experiencias diaspóricas, y en el transcurso de la investigación, de alguna manera me identificaba con los jaleños en Estados Unidos.

Ha sido un "tabú" en la antropología convencional la identificación con las personas estudiadas por parte del investigador. En las normas clásicas del análisis social se pensaba que la distancia entre el sujeto y el objeto de estudio y la desvinculación de la subjetividad del investigador con la teoría eran factores necesarios para tener el "mejor punto de vista" desde lo cual se observa el objeto de estudio. Pero, como critica Rosaldo (1989), el analista social "objetivista" es también "sujeto ubicado" en un contexto histórico sociocultural, cuya observación realizada desde una postura indiferente y una distancia con el objeto de estudio no se puede legitimar mediante criterios de razón, verdad y objetividad, ya que casi imposible desvincular una serie de factores histórico-particulares con su punto de vista. $^{2}$

En este trabajo la primera ventaja epistemológica que la aproximación al sujeto de estudio representa consiste en tomar en cuenta el papel que juegan los factores emocionales en la reconstrucción de cultura y lugar. Especialmente, este

\footnotetext{
${ }^{2}$ Criticando el "transnacionalismo objetivista" que se enfoca sólo en los datos empíricos y se enfrentan a la distancia ontológica entre el sujeto y el objeto de estudio, Federico Besserer (1999) propone el "transnacionalismo de ruptura" a partir de tres estudios: los estudios culturales, los subalternos y los pos-coloniales. Es una perspectiva que rompe con la epistemología disciplinaria de los estudios "objetivistas" e incluye la observación, experiencia y representación tanto del investigador como del trransmigrante "desde adentro" de la comunidad transnacional.
} 
trabajo se concentra en el análisis de la nostalgia, un estado de ánimo presente en la subjetividad de los miembros de la comunidad transnacional. En segundo lugar, a pesar de que el trabajo de campo se realizó en el municipio de Jalostotitlán durante un mayor tiempo que en algunas localidades en Estados Unidos, mis experiencias de desplazamiento permitieron investigar la representación de cultura, identidad y espacio, con una perspectiva amplia, en vez de entenderla por la aplicación del concepto convencional de cultura e identidad, lo cual confunde, con frecuencia, los límites sociales y culturales con las fronteras territoriales administrativas.

Hubiese sido imposible terminar este trabajo sin el apoyo de las siguientes personas y la institución. En primer lugar, quiero agradecer a Raúl Nieto Calleja, quien me acompañó durante la Maestría, por su apoyo intelectual brindado durante la redacción de dicho escrito.

Agradezco también a Mario Humberto Ruz, quien fue uno de mis asesores de la tesina, por su amistad y el apoyo recibido desde los primeros trimestres, cuando acababa de empezar mis estudios de posgrado en Antropología en México.

Con Federico Besserer, quien también fue mi asesor, tengo una deuda enorme. Él fue quien me invitó a hacer los estudios de comunidades transnacionales y diásporas, que serán el principal tema de mis estudios de los siguientes años. Gracias a él pude revisar los textos y los artículos recién publicados sobre este tema que son difíciles de conseguir en México y participar en el coloquio internacional sobre comunidades transnacionales, lo cual me dio ocasión de debutar como antropólogo en México.

Este trabajo no hubiera llegado a su fin sin la beca otorgada por el Gobierno de México, a través del Instituto Mexicano de Cooperación Internacional (IMEXCI) de la Secretaría de Relaciones Exteriores.

Finalmente, quiero agradecer a mis hermanos y mis padres por haberme comprendido cuando decidí salir de Japón y seguir enviándome su gran apoyo emocional hasta México. 


\section{CAPÍTULO 1 Viaje en seguimiento de la imagen dentro del sistema mundial}

En este capítulo explicaré el marco teórico que utilizo en esta tesis. Primero, revisaré brevemente las discusiones sobre el concepto de cultura, espacio y sujeto de estudio antropológico para ubicar los estudios de comunidades transnacionales en un nuevo desafío de la antropología. Luego, discutiré algunos límites de los trabajos anteriores de esta literatura. Por último, tomando en cuenta éstos, elaboraré un marco teórico a partir de los estudios sobre diásporas y los de turismo.

\section{Cultura, espacio y sujeto de estudio}

El término "cultura" ha sido una de las nociones claves de la antropología desde el inicio de esta disciplina. Una gran cantidad de etnografías se concentraban en la descripción y el análisis de culturas de distintas sociedades. A lo largo de la historia de la antropología, este término central se ha definido de varias maneras: un conjunto de conocimientos, creencias, artes, éticas, leyes, costumbres, y cualquier otras capacidades y costumbres adquiridas por los miembros de cierta sociedad, sistema de modos de vida, sistema de ideas, sistema de significados y símbolos, etc. ${ }^{3}$ Sin embargo, a partir de los ochenta se ha cuestionado el uso convencional de este término. En estas primeras páginas del capítulo intento hacer una breve reflexión sobre este concepto, centrando la crítica en la asociación "natural" entre cultura, gente y espacio que se ha empleado tradicionalmente al definir este término, para ubicar posteriormente los estudios de

\footnotetext{
${ }^{3}$ En esta parte, no intento abordar todas las discusiones sobre el concepto de cultura, sino que trataré de repensarlo en relación con las prácticas espaciales de la antropología. Para revisar la historia acerca del concepto de cultura y las críticas, véase el libro de Adam Kuper, 2000, Culture: The Anthrpologists' Account, Cambridge: Harvard University Press.
} 
comunidades transnacionales, que es uno de los estudios antropológicos que surgió en la crisis de la antropología. ${ }^{4}$

A pesar de tanta variedad de definiciones de cultura, lo que tiene en común el uso de este término en las etnografías clásicas es que "cultura" es un sistema de modos de vida, el de ideas o el de significados y símbolos que comparte personas que viven en ciertos espacios que tienen limites absolutos con el exterior, y por tanto, se entiende que en cada uno de estos espacios discontinuos, que se expresan como aldeas, comunidades locales, sociedades y naciones, existe una cultura distinta a la cultura de otros espacios (Clifford 1999; Gupta y Ferguson 1999). Esta premisa no sólo se ha usado en los estudios culturales de la antropología, sino también en los estudios antropológicos sobre relaciones sociales, identidades, economía, política y religión de cierta agrupación de personas o cierta sociedad.

"Cultura" (junto con el término "identidad") se ha considerado como algo "puro" que los habitantes de esos espacios "naturalmente" discontinuos comparten uniformemente (Clifford 1988) y, al mismo tiempo, como sistema de control que determina sus pensamientos, comportamientos y modos de vida. ${ }^{5}$ Por tanto, los "nativos" son objetos de estudio y objetos de control para la "cultura" a la vez. Son personas "transparentes" y "homogéneas" representadas por algunos informantes como portavoces y descritas por "el presente etnográfico" sin nombre propio ni subjetividad (Rosaldo 1989). Dado que la "cultura" y los "nativos" están encerrados en los espacios con firmes tabiques, a la manera de laboratorios, los antropólogos pueden observarlos "objetivamente" como si examinara un líquido en el frasco o ratones en una caja de vidrio. Investigar en uno de esos espacios significa estudiar una "cultura genuina" y una "identidad pura" que llenan el espacio y estudiar a los "nativos" encerrados en "la cultura" y el espacio a la vez. Según esta asociación

\footnotetext{
${ }^{4}$ La idea de esta parte fue inspirada por los siguientes artículos: James Clifford, 1999, "Culturas viajeras" y "Practicas espaciales: el trabajo de campo, el viaje y la disciplina de la antropología", en Itinerarios transculturales, Barcelona: Gedisa; Gupta y Ferguson,1999, "Beyond "Culture": Space, Identidad, and the Politics of Difference", en Akhil Gupta y James Ferguson (eds.), Culture, Power, Place: Explorations in Cultural Anthropology, Durham: Duke University Press, pp.33-51, y George E. Marcus, 1998, "Ethnography in/of the World System: The Emergence of multi-sited ethnography", en Ethnography through Thick and Thin, Princeton: Princeton University Press.

${ }^{5}$ Rosaldo, Renato, 1989, cap.4.
} 
"natural" entre cultura, espacio y gente, la antropología ha dividido convencionalmente el mundo en varios espacios discontinuos, y ha considerado como objetos de estudio a "ellos nativos" que viven fuera de los espacios en donde vivimos "nosotros antropólogos". La tarea de la antropología ha sido realizar un trabajo de campo "allá", es decir, en el espacio donde viven "ellos" y escribir las diferencias culturales entre "nosotros" y "ellos" y entre el "aquí" y el "allá".

Mientras se ha estudiado la "cultura" de cada uno de los espacios discontinuos, la antropología ha intentado analizar las relaciones entre "culturas" y "sociedades", es decir, estudiar la "cultura" de cada espacio con relación a los otros que se encuentran en el exterior del espacio estudiado. Por ejemplo, Redfield $(1941 ; 1950)$ intentó entender las relaciones entre espacios y "culturas" en términos de "folklórico / urbano", "tradicional / moderno" y "pequeña tradición / gran tradición" (little tradition / great tradition), y los teóricos del sistema mundial moderno tratan de entenderlas bajo el concepto de "centro / periferia" (Ishikawa 1993). Sin embargo, dado que estas perspectivas esencialmente están basadas en las prácticas espaciales convencionales, no rompen con las distinciones binarias modernistas de "aquí / allá" y de "nosotros / ellos". Aunque los espacios se expresan de varias formas, tales como comunidades campesinas "tradicionales", sociedades urbanas "modernas", "centros", "periferias", se considera que cada uno de los espacios tiene los límites absolutos con el exterior $y$, en su interior, una "cultura", una "identidad" y relaciones sociales particulares.

La teoría de la asimilación, que intenta comprender las relaciones sociales, comportamientos y las formas culturales de las personas que se mueven entre espacios divididos del modo convencional, también esencialmente se basa en la premisa de que existe una "cultura" en cierta sociedad o espacio. Porque, según esta idea, moverse de una sociedad a otra y vivir en el otro espacio significan ser controlado por la cultura de ese lugar, con el tiempo, aproximarse a los habitantes de ese lugar gradualmente y teñirse con el color de esa cultura y finalmente, tener la misma identidad que ellos. Por tanto, las diferencias culturales entre espacios y sociedades no desaparecen, como tampoco desaparecen las fronteras de los espacios. 
Sin embargo, mientras se hace cada vez más intensa la circulación de gente, dinero, objetos e información que atraviesa las fronteras que dividen espacios en comunidades, sociedades u naciones discontinuas, se cuestionan este concepto antropológico tradicional de "cultura" y las prácticas espaciales ligadas al dicho concepto (Clifford 1999; Gupta y Ferguson 1999; Marcus 1998). El problema de cultura antropológica tradicional y el modo convencional de dividir espacios es excluir primero del marco de la etnografía el sistema político y económico más amplio, que en realidad debe de rodear los espacios discontinuos y varias "culturas" como partes o contenidos. ${ }^{6}$

Además, al escribir, del modo convencional, una "cultura" inherente a cierta nación, sociedad o comunidad local, que se usan como marcos de la etnografía, se entiende que las diferencias culturales que permiten distinguir una "cultura" de otras son las fronteras naturales que han existido siempre, y no se cuestiona cómo el marco espacial como escena de la etnografía se ha construido históricamente dentro del mundo interconectado. Al criticar esta característica de las etnografías tradicionales, Appadurai (1988b) la denomina "confinamiento" o "encarcelamiento de nativo". El modo tradicional de la descripción de cultura encierra, incluso "encarcela" a los sujetos de estudio en los espacios separados del mundo exterior y, al mismo tiempo, los "confina" en ciertas imágenes por aplicar, uniformemente, las formas culturales descriptas en la etnografía a todas las personas que viven en ciertos espacios (Clifford 1999; Gupta y Ferguson 1999).

El tercer problema es que hoy en día, los antropólogos se encuentran, tanto en sus "campos" como en sus "hogares, ante varias realidades que no se pueden explicar por las distinciones de "nuestra cultura / cultura de ellos" y de "centro / periferia" mientras gente, bienes e información se mueven en el nivel planetario (Clifford 1999; Gupta y Ferguson 1999). No es difícil buscar varios ejemplos del

\footnotetext{
${ }^{6}$ En el capítulo 4 de su libro Anthropology as cultural critique: An Experimental moment in the Human Sciences, Chicago: The University of Chicago Press, Marcus y Fischer (1986) discuten sobre cómo se puede describir el sistema político y económico mundial en la etnografía. Aunque este libro y la noción de "critica cultural" han dado una gran influencia sobre los estudios antropológicos desde la segunda mitad de los ochenta, no lograron salir del modo convencional de definir espacio y cultura y la dicotomía entre "aquí" y "allá" y entre "nosotros" y "ellos" (Gupta y Ferguson 1999:42)]
} 
desdibujamiento de estas distinciones binarias modernistas en la vida cotidiana: los elementos culturales que se consideran como "nuestros" penetran en la vida cotidiana de "ellos" en el campo, y viceversa; "ellos", quienes deberían de estar en "las periferias", viven en "los centros" como nuestros vecinos sin que nos demos cuenta.

En cuanto a la identidad, hay varios casos de que las personas en movimiento no necesariamente forman identidades arraigadas a su origen o a su destino. Aquí también se revela el problema del modo convencional.

"En gran parte de la etnografía tradicional, el etnógrafo ha localizado lo que en realidad es un nexo regional / nacional / global, relegando a los márgenes las relaciones externas y los diversos desplazamientos de una 'cultura'"(Clifford 1999:37) y, al mismo tiempo, se han excluido de la etnografía las prácticas culturales de la gente a quien no le importan mucho las fronteras que la antropología tradicional ha empleado para delimitar el "campo" y la unidad de análisis. Sin embargo, en realidad, hoy en día, no se pueden ignorar en varias escenas de la vida diaria y en el campo los encuentros con "los nativos civilizados" que crean con su subjetividad algo así como "nosotros" o los "nativos no genuinos" (Chow 1993). ${ }^{7}$ Si no modificamos el concepto de cultura y las prácticas espaciales de la antropología, nos encontramos ante el problema de a quiénes estudiamos y "dónde se han ido todos aquellos nativos" (Chow 1993), y resulta que no podemos escribir la etnografía misma.

En una situación donde la cultura pierde su ancladero y los nativos que deberían permanecer en espacios separados viaja, ¿cómo la antropología puede repensar el concepto de cultura y el de identidad incluyendo en su alcance del análisis el sistema político y económico mundial y los movimientos de gente, dinero, objetos e información entre múltiples sitios? ¿Sobre qué tipo de objeto o sujeto de estudio podemos escribir en la etnografía con los conceptos rediseñados?

Clifford (op.cit) propone repensar los términos antropológicos, tales como identidad, cultura, tradición en términos de "viaje" en vez de entenderlos en

\footnotetext{
7 Rosaldo llamaría estos nativos como personas "culturalmente invisibles" (Rosaldo 1989: cap.9).
} 
términos de "campo" que se refiere a la residencia fija en una sola localidad relativamente autónoma y separada del exterior, una localidad del tipo "aldea" en donde Malinowski realizó su trabajo de campo, y plantea el concepto de "cultura viajera". A lo que se refiere esta noción de "cultura viajera" consiste en dos modos de definir al sujeto de estudio dentro de contextos amplios en que varios sitios están interconectados. ${ }^{8}$ En primer lugar, con el término "residencia-en-viaje", Clifford propone un acercamiento de los estudios antropológicos que permite explorar los modos en que aquellas personas que se mueven entre varios sitios construyen y representan sus prácticas culturales e identidades. Sostiene que no todos los viajeros comparten la misma experiencia de viaje. Las experiencias de la gente que vive en desplazamientos espaciales varían de "género, clases, razas, localización cultural / histórica y privilegio" (op.cit:46).

Sin embargo, para superar la tradición antropológica de describir a los sujetos de estudio como "nativos" confinados dentro de las comunidades locales separadas del exterior, lo que plantea Clifford no es que "no existen los locales en hogares, que todos son o deberían de ser - viajeros, cosmopolitas o desterritorializados. No se trata de una nomadología" (op.cit:52). Él agrega a la noción de cultura viajera un enfoque en el "viaje-en-residencia" como la segunda estrategia para definir al sujeto de estudio. Lo que sugiere con este término es estudiar a aquellas personas que no se mueven de su localidad, región o país dentro de un contexto más amplio, o sea, en un contexto interconectado con otros lugares, regiones y países por la circulación de otras personas, dinero, mercancías e información y fuerzas que atraviesan espacios. Por ejemplo, en sitios atravesados por turistas, por mercancías extranjeras, por señales de radio y televisión o por el Ejercito, los nativos no necesariamente construyen su identidad y cultura ni constituyen su mundo de vida dentro de los contextos locales bien limitados, sino en las conexiones con otros lugares. A pesar de que no realicen un viaje en el sentido literal, pueden hacer un viaje imaginario a otros sitios al construir su identidad y cultura, o las construyen en relación con la gente y los símbolos que han desplazado (42).

\footnotetext{
${ }^{8}$ Véase James Clifford, 1999, Itinerarios transculturales, Barcelona: Gedisa, cap. 1.
} 
Por otra parte, Marcus (1998) sugiere "la investigación etnográfica multilocal" para aproximarse a los sujetos de estudio que viven en el contexto más amplio que el local, es decir, el sistema político y económico mundial. ${ }^{9}$ Mientras circulan gente, bienes e información atravesando los territorios de una comunidad local y las fronteras nacionales, las actividades de la gente, las relaciones sociales, las formas culturales e las identidades no se construyen ni se representan sólo en un sitio y un contexto local, sino en y por las conexiones entre varios sitios. Por tanto, los modos tradicionales antropológicos en los cuales se realiza el trabajo de campo en un sólo sitio durante un largo plazo (aunque nos permiten captar los procesos de la formación de cultura, relaciones sociales e identidades dentro del contexto local de ese sitio) no pueden comprenderlos con relación al exterior.

Entonces, ¿cómo se puede diseñar una investigación etnográfica en/sobre el sistema político y económico mundial? Marcus, simplemente, propone que el investigador mismo se mueva de un sitio a varios sitios siguiendo a los objetos de estudio. Sostiene que esta estrategia de seguir, literalmente, a gente, objetos, historias de vida, metáfora, conflictos conforme su tema, moviéndose entre múltiples sitios, le permite entender cómo el mundo de vida y el espacio social de los sujetos de estudio se constituyen de asociaciones y conexiones entre varios sitios. Por este nuevo diseño de investigación etnográfica, se pueden describir el contexto político y económico más amplio que rodea a los sujetos de estudio por los términos etnográficos. En otras palabras, se pueden describir, desde los puntos de vista de los sujetos, los espacios en donde construyen y representan su cultura, relaciones sociales e identidades, de una manera diferente del mapeo por los conceptos antropológicos convencionales de "cultura", "comunidad" y "nación", que se caracterizan por la homogeneidad, la coherencia y los límites absolutos y firmes. Por supuesto, como señalan Gupta y Ferguson, en la situación en que los sujetos de estudio están constituyendo sus espacios sociales de una manera diferente de los modos convencionales, incluso los están "reterritorializando"

9 Marcus, George E.,1998, "Ethnography in/of the World System. The Emergence of multi-sited ethnography", en Ethnography through Thick and Thin. Princeton: Princeton University Press. Cap. 3. 
(1999:37), es necesario tomar en cuenta que este nuevo mapeo tiene que procederse en términos de clase, género, raza, sexualidad, etc.

En esta nueva dirección de la disciplina o el desafío de repensar las prácticas espaciales, sujeto u objeto de estudio y conceptos tales como cultura, comunidad, identidad, se pueden ubicar el llamado transnacionalismo o los estudios de comunidades transnacionales. Es una nueva rama de los estudios antropológicos, la cual explora los fenómenos sociales, políticos, económicas y culturales en torno a la migración transnacional con perspectivas que atraviesan las fronteras disciplinarias de las ciencias sociales. En las páginas siguientes, revisaré cuatro posiciones en la literatura sobre las comunidades transnacionales para señalar los problemas $y$, luego, introducir un nuevo enfoque en el transnacionalismo.

\section{Revisión teórica de los estudios de comunidades transnacionales}

Por lo general estos estudios emplean como unidad de análisis la comunidad transnacional que se constituye a través de la circulación constante de gente, dinero, bienes e información, que se genera en torno a la migración internacional, entre varias localidades dispersas de más de dos países. Se define el transnacionalismo, en términos generales, como "los procesos por los cuales los inmigrantes construyen campos sociales que eslabonan juntos su país de origen y su país de asentamiento" (Glick Schiller et al. 1992a:1).

Sin embargo, hay distintas posiciones para teorizar la comunidad transnacional y el transnacionalismo. Algunos autores se aproximan a ella desde el análisis sobre formas de organizaciones políticas de los migrantes, su identidad y relaciones con el Estado-nación, y otros la estudian a partir de relaciones familiares que los migrantes construyen atravesando las fronteras nacionales $u$ objetos culturales que circulan entre las localidades dispersas transnacionales.

Según Rouse, en los estudios de la migración mexicana a Estados Unidos, han sido dominantes tres perspectivas basadas en los discursos modernos. En primer lugar, el sitio de origen de los migrantes y los asentamientos se entienden como "comunidades", espacios o lugares discontinuos con límites, en donde las relaciones sociales de sus habitantes son más intensas dentro de tales espacios 
que afuera. Por lo tanto, la migración se define como movimiento de una "comunidad" a la otra, de un ambiente sociocultural al otro. En segundo lugar, la migración de regiones rurales de México a Estados Unidos se entiende como movimiento de la "periferia" al "centro". En el tercero, los movimientos espaciales de los migrantes de la "periferia" al "centro" significan desplazamientos de las relaciones sociales y la cultura de su origen a las otras de nuevos asentamientos. Además, la gente que se ha movido a otra "comunidad", se supone, se va a asimilar al nuevo ambiente sociocultural, por lo tanto, las fronteras y las diferencias por las cuales se distinguen una sociedad de otra no desaparecen.

Sin embargo, estas imágenes espaciales modernistas, sostiene Rouse, no son adecuadas para comprender los espacios sociales que se han constituido a través de la migración entre México y Estados Unidos. Según él, tanto el lugar de origen como el asentamiento no son espacios discontinuos. Por ejemplo, en el caso de los migrantes aguilillenses, a pesar de que se han establecido por largo periodo en Redwood City, California, la mayoría de ellos no han abandonado su lugar de origen, sino que siguen manteniendo los contactos con sus familiares en el municipio de Aguililla, Michoacán, a través de remesas, comunicación telefónica y visita temporal. En este caso, el espacio en donde sus relaciones sociales operan y se construyen no se limita solamente al lugar de origen 0 al asentamiento, sino que se constituye de múltiples sitios.

Para entender este nuevo espacio social que los aguilillenses han construido, Rouse usa el término "circuitos migratorios transnacionales". Según él, a través de la circulación continua de gente, dinero, bienes e información entre el lugar de origen y nuevos asentamientos de los migrantes, se desarrollan circuitos migratorios transnacionales que constituyen una sola comunidad dispersa en una variedad de localidades. En esta nueva imagen de comunidad, tampoco son válidos la distinción espacial absoluta de "centro/periferia" y el modelo de asimilación, ya que los migrantes transnacionales han convertido los asentamientos en lugares que tienen habitantes y modos de vida identificados en la "periferia" sin perder sus diferencias culturales y lingüísticas, y al mismo tiempo, en el lugar de origen, los modos de vida de Estados Unidos y las influencias 
culturales extranjeras se han difundido por la televisión y la migración. Para Rouse, la comunidad transnacional que se constituye en los circuitos migratorios, que atraviesan las fronteras nacionales, es un "hiperespacio posmoderno" (Jameson 1984), es decir, "nuevo tipo de espacio que nuestras sensibilidades modernas no pueden captar" (Rouse 1991:8).

Empleando esta perspectiva posmodernista, Kearney también define el transnacionalismo como "un desdibujamiento, o, quizá, mejor dicho, un reordenamiento de las distinciones binarias culturales, sociales y epistemológicas del periodo moderno" (1991:55). Al estudiar las comunidades mixtecas transnacionales constituidas de varias localidades en California y en Oaxaca, sobre todo las relaciones entre las organizaciones políticas indígenas y el Estado-nación, Kearney sostiene que los migrantes mixtecos construyen una identidad que escapa de los discursos del Estado-nación ligados a la firme distinción entre el nacional "nosotros" y el distante "ellos".

Según él, en las "áreas fronterizas" transnacionales, los mixtecos se definen como "otros", "extraños" y subalternos tanto frente a la nación mexicana como a la estadounidense. En México, ellos son "otros", diferenciados de la "nación mestiza" y destinados a la asimilación a ella y luego, a su desaparición. En Estados Unidos, son "extraños" cuya ciudadanía es negada, dado que la mayoría de ellos atraviesan la frontera norte de México sin papeles. Sin embargo, los miembros de las comunidades mixtecas transnacionales desafían sus condiciones subalternas y el poder del Estado-nación, y redifinen su identidad a través de sus organizaciones políticas. El objetivo principal de estas asociaciones es defender los derechos humanos de los miembros de las comunidades indígenas en California y lograr una autonomía de las comunidades de origen en Oaxaca sin la intervención política del gobierno mexicano por la utilización de recursos económicos de las asociaciones de los migrantes (1992). A través de estas asociaciones se han abierto la posibilidad de reconstruir comunidades indígenas autónomas que puedan escapar a la sujeción del Estado y a la vez desafiar las condiciones subalternas que ambos Estados definen. Además, al construir un espacio relativamente autónomo y libre de los discursos del Estado, ellos pueden 
conservar sus diferencias sociales, culturales y étnicas y reconstruir la etnicidad como identidad étnica constituida por diferencias, en vez de nivelarlas por la presión de asimilación y aculturación por parte de los Estados. En suma, las comunidades transnacionales que estudia Kearney son comunidades que se consolidan en "la era de pos-nacionalismo" (1991:55), en un momento de desvanecimiento del Estado-nación.

En contraste con el transnacionalismo como "muerte del nacionalismo" o "pos-nacionalismo" que plantea Kearney, Glick Schiller y sus coautoras (1992a; 1992b) lo definen como nuevo proceso de la construcción del Estado-nación al responder a la migración transnacional. En términos generales, para ellas, el término "transnacionalismo" se refiere a "los procesos por los cuales los inmigrantes construyen campos sociales que eslabonan juntos su país de origen y su país de asentamiento" (1992b:2). Definen como "transmigrantes" a aquellos inmigrantes que construyen tales campos sociales atravesando los límites nacionales.

A diferencia del concepto de etnicidad como identidad étnica alternativa a la conciencia nacionalista que plantea Kearney, Glick Schiller y sus coautoras sostienen que en el caso de la migración caribeña a Nueva York, la construcción de las comunidades transnacionales y la formación de identidad étnica de los transmigrantes no están libres del poder del Estado-nación, sino que han surgido como resistencia y acomodación a los procesos políticos de la nación de asentamiento y las naciones de origen. En el pasado, la identidad étnica era una identidad por la cual los grupos étnicos minoritarios resistían a los procesos hegemónicos de la nación estadounidense, una identidad alternativa a la conciencia de "gente americana" (American people) como identidad homogénea nacional que se refería solamente a la gente de piel blanca. Sin embargo, a medida que se han extendido los movimientos de los derechos civiles desde los años sesenta, la nación estadounidense ha ampliado la categoría de "gente americana". En una nueva versión de la Nación, el pueblo estadounidense se compone de una multiplicidad de poblaciones étnicas y se caracteriza por el pluralismo cultural. Por ejemplo, en este concepto, el gobierno "etnifica" a los 
inmigrantes haitianos como grupo étnico que forma parte del mosaico cultural del país para incorporar a los procesos políticos de la nación estadounidense. Al responder a este nuevo proyecto de construcción del Estado-nación estadounidense, los inmigrantes construyeron las organizaciones políticas que pudieran identificarlos a ellos mismos como representantes de la "comunidad haitiana" en Estados Unidos para buscar su seguridad y sus intereses en este país.

Por el otro lado, las naciones de origen de los transmigrantes también están ejerciendo un nuevo proyecto de construcción del Estado-nación (1992a; 1992b; Basch et al. 1994). Por ejemplo, el presidente de Haití, al reconocer el papel importante que juegan los transmigrantes para la economía y la política del país, designó, en 1991, a la comunidad diaspórica haitiana en Nueva York como el dizyem, el décimo distrito político de la nación haitiana. En otras palabras, el Estado y las elites políticas están intentando extender las fronteras nacionales para incorporar las comunidades de los transmigrantes ubicadas geográficamente, en el sentido estricto, dentro de los territorios de otro país, a la nación de origen como "Estado-nación des-territorializado" (Basch et al., op.cit.).

En resumen, lo que plantean Glick Schiller y sus coautoras es que la construcción de las comunidades transnacionales y la identidad colectiva de sus miembros no están libres de los procesos hegemónicos del Estado-nación. Los transmigrantes son sujetos creativos que construyen nuevos espacios sociales más allá de las fronteras nacionales, pero, al mismo tiempo, también son objetos del control y de nuevos proyectos del Estado-nación. En el caso estudiado por ellas, tanto la nación de asentamiento como la nación de origen están redefiniendo los proyectos de la construcción del Estado-nación al responder al desarrollo de las prácticas transnacionales de los migrantes. Por lo tanto, para estas autoras, el momento que Kearney llamó "la era de transnacionalismo" no es "la era de posnacionalismo" ni "el fin del imperio". En su caso, el transnacionalismo implica procesos continuos e intensificados de la construcción del Estado-nación en la nación de asentamiento y en las naciones de origen. 
A pesar de que haya diferencias en la definición de transnacionalismo y en el modo de aproximarse a las comunidades transnacionales entre estos autores, que fueron pioneros de los estudios transnacionales de la migración, los sujetos de estudio son los migrantes, aquellos que viajan literalmente atravesando los límites nacionales. Estos autores explican cómo estos sujetos transnacionales imaginan sus espacios sociales y construyen nuevos modos de vida que no se limitan al único contexto local y nacional. Según su concepto de comunidad transnacional, todos plantean en común que el lugar de origen forma una parte o un punto de la comunidad transnacional. Por tanto, los habitantes de ese lugar también deben de ser miembros de la comunidad transnacional.

Sin embargo, en sus discusiones, los puntos de vista de la gente que se queda en el lugar de origen están excluidos del análisis. ${ }^{10}$ Esta perspectiva limita el privilegio de crear un nuevo modo de vida, una nueva realidad e identidad en el espacio transnacional sólo a los migrantes. En consecuencia, la gente que se queda en los lugares de origen que forman parte de ese espacio aparece como miembro secundario e incluso invisible.

Es lógico que los estudios de comunidades transnacionales tienden a analizar tales nuevos espacios poniendo tanto énfasis en los migrantes, ya que los espacios transnacionales que estudian se han formado principalmente a raíz de la migración transnacional. No obstante, el problema es que los análisis sobre las comunidades transnacionales solamente a partir de las acciones y los puntos de vista de los migrantes excluyen de la discusión visiones del mundo y actividades creativas de otros habitantes que viven en el contexto transnacional y no cruzan las fronteras nacionales físicamente.

Otro problema de estos trabajos es que, dado que los puntos de vista de los habitantes de los lugares de origen están excluidos del análisis, estos autores no analizan el problema de desigualdad y relaciones asimétricas de poder entre los lugares de origen y los asentamientos y entre los habitantes de los terruños y los

\footnotetext{
${ }^{10}$ Es cierto que Glick Schiller y sus coautoras (1992a; 1992b) prestan atención a los lugares de origen de los transmigrantes, pero, sólo explican las perspectivas del gobierno y las elites de las naciones, no los puntos de vistas de los habitantes de las localidades de donde los transmigrantes han salido.
} 
migrantes dentro de las comunidades transnacionales y cómo contribuyen una y otra parte en el proceso.

En este sentido, los estudios de comunidades transnacionales que he revisado se basan en la primera estrategia que propone Clifford para estudiar conexiones entre múltiples sitios: "residencia-en-viaje". Sin embargo, como he mencionado, las "culturas viajeras" que él plantea no es una estrategia solamente para analizar a la gente en movimiento, sino también implica el "viaje-enresidencia", una estrategia para enfocar en la gente inmóvil que desplaza sus modos de vida, cultura, identidades, relaciones sociales y el mundo de vida a través de los encuentros con la gente, bienes e información en movimiento y las conexiones con otros lugares a pesar de no realizar un viaje en el sentido literal.

En la etnografía tradicional, los sujetos que atraviesan los límites de los espacios discontinuos han sido excluidos de la etnografía o relegados a las márgenes del marco etnográfico. Los estudios de comunidades transnacionales desafían esta tradición antropológica, rompen con la asociación "natural" entre cultura, espacio y gente y proponen nuevas perspectivas para investigar los espacios, enfocando en la gente que atraviesa los límites espaciales convencionales. Pero, ahora, irónicamente, resulta que las personas que no están en movimiento, o sea, aquellos que han sido descritos como "nativos" en la etnografía tradicional, son invisibles.

Existe, sin embargo, un trabajo que plantea el transnacionalismo de una manera distinta a los teóricos de esta literatura que he criticado. La autora del trabajo, en contraste con los otros autores, utiliza las dos estrategias que plantea Clifford para describir culturas viajeras al estudiar las conexiones entre asentamientos y lugar de origen y la construcción de una comunidad transnacional.

Como otros autores de la literatura de comunidades transnacionales, Boruchoff (1999) también afirma que el transnacionalismo implica nuevas configuraciones complejas de poder, riqueza, relaciones sociales, afiliaciones políticas y entendimientos culturales que transcienden límites nacionales y desafían nuestro convencional modo de entender el mundo conforme a la 
supuesta visión moderna de que el mundo se divide "naturalmente" en espacios discontinuos, tales como "comunidades", "centro / periferia", "naciones", con una coherencia interna y límites espaciales firmes. Además, igual que el concepto de comunidad transnacional que plantean los demás autores, sostiene que por medio de la constante circulación de personas, bienes, dinero e información entre localidades específicas ubicadas en distintas naciones, estos sitios se han entrelazado para formar una entidad singular transnacional, es decir, una comunidad transnacional (Boruchoff 1999).

Sin embargo, a diferencia de los planteamientos de los otros, Boruchoff, al prestar más atención al aspecto de que el lugar de origen forma parte de este singular contexto transnacional, agrega al transnacionalismo la siguiente referencia: "el transnacionalismo no es una cuestión simplemente de las personas que emigran; más bien abarca una sociedad más amplia que no sólo incluye a los familiares de migrantes que nunca se han alejado de sus pueblos natales, sino también incluye a las familias no migrantes" (1999: 500).

Para explicar esta idea concretamente, analiza la construcción de la comunidad transnacional en la dimensión de la "práctica" y la conciencia de los habitantes de varias localidades geográficamente dispersas entre Chicago y Iguala, Guerrero, en vez de enfocarse solamente en los migrantes y sus acciones en el nivel de organizaciones y estructuras políticas económicas formales como lo hacen Kearney y Glick Schiller et al. En otras palabras, ella estudia cómo interpenetran las fuerzas económicas y políticas formales en los detalles de la vida diaria de la gente y cómo la gente se imagina y construye una esfera social transnacional constituida de múltiples sitios y su conciencia de vivir en una comunidad transnacional.

Acompañando a los movimientos de la población entre México y Estados Unidos, han proliferado los objetos derivados del lado opuesto de la frontera tanto en asentamientos como en pueblos natales de migrantes. Boruchoff no sólo considera estas afluencias de bienes extranjeros como procesos de la penetración de las economías extranjeras, sino también como afluencias de signos que representan personas y lugares geográficamente distantes. Además, sostiene que 
a través de los objetos, se forman las conexiones simbólicas entre varios sitios específicos de ambos lados de la frontera internacional entre México y Estados Unidos. Por ejemplo, al regalar a las personas que están en el otro lado de la frontera ciertos objetos, tales como fotos y cintas de video de algún evento social en una localidad, ropa, etc., aquellos individuos que regalan los objetos pueden mantener viva su presencia en el lugar en donde se encuentran los receptores de los mismos, a pesar de su ausencia física. Por otro lado, aquellos que reciben los materiales extranjeros interpretan las experiencias que viven quienes se los regalan, y guardan en sus conciencias las localidades representadas por medio de los objetos. De esta manera, las personas que se encuentran en distintos sitios entre ambos lados de la frontera pueden efectuar interacciones sociales a pesar de distancias geográficas. En suma, una diversidad de objetos sirven como medio material o puente para que una población dispersa entre ambos lados de la frontera "se constituya como una comunidad, entretejiéndose los sitios que habitan colectivamente para crear un sólo contexto social" (1999:502). En este sentido, para ella, ambos, migrantes y personas que se quedan en el lugar de origen, son sujetos creativos que participan en la construcción de las comunidades imaginadas transnacionales. ${ }^{11}$

Al enfocar en ambas categorías de miembros de la comunidad transnacional, Boruchoff logra describir a los habitantes del terruño de los migrantes como sujetos que constituyen su mundo de vida en el contexto más amplio que el contexto local y "viajan" a otros lugares que están más allá de la frontera norte a través de las imágenes que evocan los objetos culturales derivados de otros lugares, no como "nativos confinados" en un sólo sitio en donde se encuentran físicamente.

Sin embargo, como los demás autores, ella tampoco aborda el problema de desigualdades entre varias localidades que constituyen una comunidad transnacional ni las relaciones asimétricas de poder entre los migrantes y los habitantes del lugar de origen.

\footnotetext{
${ }^{11}$ Anderson (1983) utiliza el término comunidades imaginadas, para analizar, sobre todo los procesos de la construcción de Estados-nación.
} 
Cuando revisemos algunos estudios sobre el retorno de los migrantes a sus terruños, se cuestionará la supuesta idea de las comunidades transnacionales como espacios utópicos que están lejos de tener conflictos. Al construir las conexiones entre asentamientos y lugares de origen, las relaciones entre la gente que ha salido de pueblos natales y los habitantes de esos lugares se vuelven a veces problemáticas.

\section{Las negociaciones de la presencia en el terruño y los conflictos}

Generalmente el retorno de los migrantes a sus lugares de origen en México durante la temporada de fiestas se ha entendido como una ocasión de vinculación y estrechamiento de relaciones entre la gente que se queda en ese lugar y la población que ha salido a otro país (Durand 1994:319) o como oportunidad de revalidación de su membresía en las comunidades locales (Lopéz y Cedestrom 1991). ${ }^{12}$ Por otra parte, Goldring (1997), Montes (1992) y Espinosa (1999) prestan más atención a los aspectos conflictivos del retorno.

Goldring, aunque enfoca solamente en los migrantes, por un lado, afirma que la fiesta en el pueblo de Las Ánimas, en el sur de Zacatecas, permite a los trabajadores migratorios gastar y generar dinero a favor del desarrollo de la comunidad local, y que la fiesta es "una celebración e identificación importante de la pertenencia al pueblo" y "proporciona un contexto que permite tanto a los trabajadores migratorios como a los habitantes no migrantes alternar y renover los lazos" (Goldring 1997:80). Por el otro lado, considera que el retorno es una ocasión en que los migrantes y sus familias "puedan exhibir su poder de consumo y afirmar la distinción social" entre las demás personas con quienes comparten un sentido de identidad de comunidad (1997:90).

Olga Montes (1992), quien estudia los impactos de la migración a los Estados Unidos en una comunidad del estado de Oaxaca, señala que al regresar del Norte, los migrantes han desplazado del sistema de cargos a los lugareños que tienen el poder económico por el comercio local y regional. Al regresar con recursos

\footnotetext{
${ }^{12}$ Durand (1994) analiza la función de las fiestas religiosas en el occidente de México, sobre todo las fiestas en Los Altos de Jalisco en una sección del capítulo siete.
} 
económicos que han ganado en el otro país, los migrantes disputan la mayordomía y el poder político en la comunidad de origen a la elite tradicional del pueblo.

Espinosa (1999) analiza los procesos históricos y socioculturales de la creación del día del emigrante, una nueva ceremonia religiosa de la iglesia católica en el pueblo de San Diego de Alejandría en los Altos de Jalisco. Señala que anteriormente la iglesia católica local se preocupaba por el regreso de los migrantes y los rechazaba considerándolos como causantes de la mayoría de problemas sociales en el pueblo, ya que regresaban con demasiado dinero y con ideas y comportamientos que chocaban con los valores y las prácticas del catolicismo. Sin embargo, cuando el número de los habitantes que salían a los Estados Unidos aumentó y el papel económico, política y cultural que jugaban los migrantes en su pueblo de origen se incrementó, la iglesia tuvo que cambiar esta actitud negativa hacia los migrantes. En este contexto, creó este nuevo ritual para incorporar a los migrantes tanto a la iglesia como a la comunidad de origen.

Como estos casos indican, al reincoporarse en los lugares de origen y negociar su pertenencia a través del retorno y la participación en las fiestas en las comunidades de origen, la relación entre los migrantes y los habitantes de los lugares de origen, en ocasiones, se vuelve problemática.

Aparte de reclamar su pertenencia por los contactos reales físicos con los lugares de origen, hay otra manera de mantener viva su presencia. Como sostiene Boruchoff, la presencia de los ausentes se busca por medios de los símbolos. Pero, cuando ellos intentan reconstruir un terruño que tenga los espacios en los que se puedan inscribir los signos de su presencia, los vínculos establecidos entre los asentamientos y las comunidades de origen, a través de los cuales circulan los símbolos, no pueden ser vistos como una simple conexión simbólica. Por ejemplo, el dinero que envían los migrantes y lo que se ha construido con tales recursos económicos también se pueden considerar como símbolos que hacen patente su presencia en las comunidades de origen. Goldring señala que las inversiones de dólares que los migrantes han ganado en los Estados Unidos en los proyectos colectivos de la comunidad local, tales como la construcción de edificios escolares, 
la restauración de la iglesia, la pavimentación de caminos, etc., no son ajenas a los conflictos (1997:86-89). A veces, los proyectos colectivos de la comunidad local costeados por recursos movilizados por los migrantes generan algunas cuestiones: ¿a quién beneficiarían más, a los migrantes o a los habitantes del pueblo que no emigran? ¿Qué tipo de comunidad estos inversionistas se imaginan y desean crear para ellos mismos?

En el contexto en que la existencia y los apoyos de los migrantes se vuelven cada vez más indispensables para el desarrollo y supervivencia de las comunidades en México que se enfrentan con el problema de despoblación por la migración, y que los retornados consiguen el poder político local reemplazando a los líderes locales tradicionales, al diseñar el proyecto de la reconstrucción de comunidades locales, es inevitable que se tomen en cuenta, en un grado considerable, los intereses y las expectativas de los migrantes como patrones financieros y nuevos líderes políticos locales. Aquí, las cuestiones que surgen son qué tipo de lugar de origen se reconstruye y a qué tipo de terruño los migrantes esperan pertenecer. En una palabra, el punto central de estas cuestiones es qué imágenes de terruño los migrantes describen.

$\mathrm{Si}$ entendemos los vínculos que se han establecido entre los nuevos asentamientos en el país de destino y los lugares de origen no solamente como simples conexiones económicas y simbólicas y rutas de los movimientos de población de ida y vuelta, sino también como relaciones políticas y de desigualdad, resulta necesario analizar las imágenes de terruño en sí en términos de desigualdad.

Para hacer más énfasis en este punto, agregaré a la discusión el concepto de "zona de contacto" (contact zone) que plantea Pratt (1992). Al estudiar cómo fueron recibidos y apropiados por los colonizados y grupos subordinados los modos en que los dominantes y colonizadores representan la colonia y su cultura, ella usa este término que se refiere "al espacio en donde poblaciones, geográfica e históricamente separadas entran en contacto una con otra y establecen relaciones continuas, usualmente, incluyendo coerción, desigualdad radical y conflicto intratable" (6). 
Aunque su uso de los términos "contacto" y "metrópoli / periferia" podría ser confundido con la idea del contacto entre una "cultura" con absolutos límites espaciales y otras, el objetivo principal del uso de este concepto es hacer hincapié en el siguiente punto: "de qué modo los sujetos están constituidos en y por sus relaciones recíprocas. Se trata de las relaciones entre colonizadores y colonizados, o viajeros y "viajados" ("travelees"), no en términos de separación o apartamiento, sino en términos de copresencia, interacción, entendimientos y prácticas trabadas, a menudo dentro de relaciones de poder radicalmente asimétricas" (7).

Esta perspectiva es útil, no sólo para ver las relaciones entre colonizadores y colonizados y entre estados que poseían la soberanía de la colonia y los estados recientemente independizados de tales colonias, sino también para explorar relaciones entre dominantes y subordinados en "situaciones pos-coloniales". E término "situación pos-colonial" se refiere a la situación en que se constituyen las relaciones inequitativas, conflictivas y discriminatorias entre dominantes y subordinados dentro de una nueva nación recientemente independizada de la metrópoli colonial. Esta situación no solamente se observa en el nivel nacional, es decir, en relaciones entre las elites del gobierno de la nación y el pueblo en general, sino también en niveles micros, por ejemplo, en relaciones entre las elites y los demás habitantes de una comunidad local (Maeyama 1994).

Es cierto que los movimientos migratorios transnacionales ocurren dentro del sistema del capitalismo mundial, y que los migrantes se encuentran en una condición subalterna en la situación pos-colonial dentro los países de destino. Pero, al regresar a sus lugares de origen con mayor recursos económicos y ocupar importantes puestos en la organización de las fiestas en sus pueblos, este otro desplazamiento genera otra situación pos-colonial en sus lugares de origen, y reemplazan su posición subalterna por la dominante. En este sentido, es correcto que al estudiar a los sujetos dentro del sistema político y económico mundial siguiéndolos de un sitio a varios sitios, pero, como dice Marcus, ellos no necesariamente son aquellos que se sitúan en una posición fija subalterna en el sistema político y económico mundial aunque la etnografía respecto al sistema 
mundial generalmente enfoque en sujetos subalternos bajo la dominación sistemática (Marcus 1998:85-86).

Tomando en cuenta los enfoques en los cuales estos dos conceptos hacen énfasis, considero el retorno como "encuentro pos-colonial", un encuentro que genera nuevas formas de dominación y relaciones asimétricas de poder y, al mismo tiempo, considero los lugares de origen como "zonas de contacto" en donde los migrantes y los habitantes de sus lugares de origen se "reencuentran". Obviamente, al usar la palabra "contacto", no me refiero al contacto entre distintas culturas o contacto entre dos sujetos distintos que pertenecen respectivamente a una "cultura". Más bien, lo que quiero destacar en este estudio al usar este término es que a través del "reencuentro" entre estos dos sujetos, las imágenes que cada uno de ellos describe hacia el terruño y los intereses en ello también se contactan. Por supuesto, dado que las diferencias entre ambos categorías de la gente y las categorías en sí han sido constituidas histórica y políticamente a través de los movimientos de población de ida y vuelta entre los asentamientos y los lugares de origen (Gupta y Ferguson 1999), no se puede definir esta división categórica como algo "natural" que siempre ha existido. No obstante, si se trata de un retorno como turismo, los sujetos se constituyen nuevamente en los procesos de la producción y el consumo de las imágenes sobre el terruño, no sólo porque se constituye una nueva división categórica de turistas / anfitriones, sino también porque ambos sujetos producen y consumen las imágenes sobre sí mismos y los "otros" en sus relaciones recíprocas.

En suma, el transnacionalismo que propongo aquí es que, en primer lugar, tanto los habitantes que se quedan en el lugar de origen como los migrantes son sujetos que participan en la construcción de las comunidades transnacionales, y ambos son sujetos creativos que viven nuevas formas culturales, identitarias y de relaciones sociales. En segundo lugar, las relaciones entre ambos no son relaciones que estén lejos de generar conflictos. En tercer lugar, entrar en los procesos de la transnacionalización de la vida y tener conexiones con otros lugares dentro de un contexto más amplio significan ser enredado en nueva configuración de la relación de poder compleja. Pero, como sostiene Foucault 
(1982:220), "ser enredado en una malla de relaciones de poder abre la posibilidad de nueva resistencia y creación".

El objetivo de este capítulo es, tomando en cuenta estas tres propuestas del transnacionalismo, construir una perspectiva teórica para ver la dinámica de la construcción de lugar de origen, cultura e identidades en el lugar de origen de los migrantes como "zona de contacto" a través del encuentro entre los migrantes y la población no migrante en "una situación pos-colonial".

\section{Metodología de seguir la imagen}

Aunque este encuentro ocurre en el lugar de origen, en este contacto, varios sectores de múltiples sitios están involucrados: los migrantes, los habitantes del lugar de origen, las organizaciones de migrantes en los asentamientos, el municipio del lugar de origen, la política estatal, el gobierno mexicano, el estadounidense, etc. Para explorar cómo lo que ocurre en otros sitios influye en el lugar del encuentro dentro de un mundo interconectado, utilizo la metodología de seguir que propone Marcus (1998). En mi caso, voy a seguir la imagen sobre el terruño para recorrer múltiples sitios. Para analizar las imágenes, el fetichismo metodológico que propone Appadurai (1991) resulta muy sugestivo. En cierto sentido, las imágenes que se estudian en este trabajo son mercancías. Él sostiene que el valor está en las mercancías, pero, lo que representan las mercancías se crea por el intercambio. El fetichismo metodológico que propone Appadurai no se refiere a enfocar solamente en los símbolos y el valor que las mercancías representan, sino seguir las cosas-en-movimiento para revelar su contexto social y político. En otras palabras, "las mercancías, como las personas, tienen una vida social” (Appadurai 1991:17). ${ }^{13}$ Por tanto, seguir la imagen es una perspectiva estratégica para analizar lo que cada imagen representa y, al mismo tiempo,

\footnotetext{
${ }^{13}$ Como señala Chow (1993), Appadurai personifica las mercancías, pero, no incluye a las personas en la categoría de las mercancías. La fuerza de la comercialización en el capitalismo no hace distinción entre personas y mercancías. En el caso de la migración, las personas son mercancías que se venden y se compran. También son mercancías los "nativos" como "especímenes exóticos o étnicos" en el turismo (véanse Bruner, Edward, "Of Cannibals, Tourists, and Ethnographers", Cultural Anthropology, 1989, 4(4): 438-445. y Lutkehaus, Nancy Christine, "'EXCUSE ME, EVERYTHING IS NOT ALL RIGHT': On Ethnography, Film, and Representation", Cultural Anthropology,1989, 4(4): 422-437.
} 
estudiar las relaciones sociales y políticas en las que se basan la producción y el consumo de dicha mercancía. En este sentido, partiendo del análisis simbólico, lo que intento estudiar son las interacciones, las relaciones de poder y las negociaciones entre los turistas y los anfitriones en un mecanismo de producción y consumo de imágenes.

Como veremos más adelante, las imágenes de un lugar que describe en su mente la gente, que se encuentra espacial y temporalmente lejana de ese lugar, o sea, los lugares imaginarios se forman de varias maneras: se construyen en el nivel individual por la combinación de memorias e imaginación; en el nivel macro, se forman a través de las imágenes, o sea, los símbolos que producen la industria de turismo, los medios masivos de comunicación y el Estado y la circulación de otras mercancías, que transmiten los símbolos, entre el lugar de donde inicia el viaje y el lugar de destino. Estos factores inspiran a la gente la nostalgia hacia ese lugar lejano que imagina.

Lo que sucede al promover el viaje masivo a un lugar determinado para satisfacer la nostalgia hacia el lugar imaginario es la creación de la hiperrealidad en el lugar de destino. Baudrillard (1978) y Eco (1999) sostienen que el efecto de la hiperrealidad le hace a uno confundir los limites entre el original o el primario y la copia y entre la realidad y la ficción. Según Baudrillard, hoy en día, en ocasiones, los simulacros proceden a la realidad e "intentan hacer lo real, todo lo real, con sus modelos de simulación" (Baudrillard op.cit:10). Por lo general, pensamos que la ficción es un simulacro de la realidad y que la realidad procede a la ficción. Pero, en este orden de los simulacros, es al revés: la realidad nace de la ficción e imita a la ficción.

Uno de los casos extremos de este orden de los simulacros es Disneylandia (California). La animación Disney, primero, nació de la imaginación de Walt Disney. Su mundo imaginario y de fantasía se les transmite a millones de personas a través de la pantalla de la televisión, del cine, libros y juguetes. Este lugar de diversión se construyo para materializar el mundo imaginario de Walt Disney y el de millones de los consumidores de su fantasía. Es un lugar más "verdadero" y "real" que el primario (la animación o el imaginario de Walt Disney) 
aunque este lugar es real y existente pero nacido de la ficción, no de la realidad alguna, dado que ahí, el mundo Disney, que está en el espacio de la segunda dimensión originalmente, está en nuestro mundo y se ha construido no con animales antropomorfizados, sino con seres humanos (Eco 1999). En pocas palabras, la hiperrealidad anula los limites entre la ficción y la realidad. Es una realidad construida por la materialización del lugar imaginario. Pero "no se trata de imitación ni de reiteración, incluso ni de parodia, sino una suplantación de lo real por los signos de lo real (Baudrillard 1978:11). Es más verosímil que el primario y lo real: es lo hiperreal.

Al materializar el lugar imaginario que describen los viajeros, el lugar real se reconstruye, incluso las tradiciones y las culturas locales se modifican para crear una hiperrealidad. En la segunda parte de seguir imágenes, centraré la discusión en el tema del consumo cultural de las imágenes sobre lugar donde se materializa el lugar imaginario. ¿Quiénes son consumidores o audiencias de la hiperrealidad? ¿Cómo se relacionan los productores de imágenes y los consumidores? Obviamente, los turistas son productores y consumidores de lo imaginario a la vez, y la industria de turismo, los medios de comunicación y el Estado también son productores. Pero, este esquema simplista no nos ayuda a revelar suficientemente el complejo mecanismo de la producción y el consumo de lugar imaginario. Como dice García Canclini (1995), "los procesos de consumo" son "algo más complejo que la relación entre medios manipuladores y audiencias dóciles", y "la hegemonía cultural no se realiza mediante acciones verticales en las que los dominadores apresarían a los receptores", se requieren los mediadores (1995:41-42). A lo que se tiene que prestar atención es la existencia de la sociedad anfitriona, ya que es imposible el proyecto de la creación de la hiperrealidad sin el fundamento sobre el cual se construye y se reifica el lugar imaginario con la decoración de los signos de lo real ni la participación de los anfitriones. Para que sea táctil y visible el imaginario, el lugar se debe reconstruir con los objetos reales y los seres humanos reales en los cuales están inscritos los signos. De tal manera, se modifican, se fabrican, incluso se inventan los paisajes y las tradiciones locales como los signos de lo real, y también se movilizan los nativos de la sociedad anfitriona como 
mediadores para que se puedan transmitir los mensajes a los turistas a través de sus actuaciones.

Además de jugar el papel de mediadores, los anfitriones también son audiencias del espectáculo hiperrealista. Algunos sectores de la sociedad anfitriona se apropian de las imágenes sobre su terruño y sobre sí mismos producidas por los otros, y consideran el imaginario como lo propio y lo real. No obstante, como veremos más adelante, no todos los sectores de la sociedad receptora son agentes mediadores y consumidores dóciles a la nostalgia y las imágenes hegemónicas del lugar ni les adscriben el único significado a las imágenes (Gledhill 1999:31-32). Existe la heterogeneidad en la categoría de los nativos de la sociedad anfitriona. ${ }^{14}$ Algunos sectores están de acuerdos en la reconstrucción de lugar conforme a la nostalgia hegemónica, y otros se oponen y resisten a la reconstrucción de su propio lugar que se realiza dando prioridad a las expectativas de los turistas y los dominantes de la sociedad. Por tanto, al seguir imágenes, se observa una relación de hegemonía y resistencia entre quienes emiten los mensajes y quienes los reciben.

Sin embargo, este esquema es aún demasiado simple como para permitirnos captar una dinámica más compleja de los procesos de la reconstrucción de lugar y cultura local en un contexto en donde se entrecruzan los canales de los símbolos derivados de múltiples sitios. Si se analiza los vínculos entre los turistas y los nativos en términos de interacción de negociación, ductilidad e hibridación (García Canclini 1995: 42, 116,170-171), ${ }^{15}$ se pueden observar los sectores de los locales que se apropian de las imágenes producidas por los otros pero, al mismo tiempo, producen otras imágenes y modifican la combinación de los signos, participando en la escena hiperrealista, para reificar un lugar imaginario que puedan considerar como propio. El bricolaje que crea la hiperrealidad recombinando los signos no sólo es el privilegio de los dominantes; los subalternos también lo utiliza para negociar sus territorios e identidades. En

\footnotetext{
${ }^{14}$ Para consultar la heterogeneidad de consumidores, audiencias y ciudadanos, véase el libro de Néstor García Canclini, 1995, Consumidores y Ciudadanos: Conflictos multiculturales de la globalización, México, grijalbo.

${ }^{15}$ También véase el capítulo V del libro de García Canclini, 1989, Culturas Híbridas: Estrategias para entrar y salir de la modernidad, México, Grijalbo.
} 
suma, las redes del consumo de imágenes del terruño son "un espacio de luchas, un terreno de memorias diferentes y un encuentro de voces desiguales" ${ }^{16}$ y los lugares imaginarios son “escenas' de evasión” o de contienda (García Canclini 1995:196).

A continuación, "armaré" la metodología del cómo seguir las imágenes concretamente, sobre todo a partir de las perspectivas de los estudios de diásporas y los de turismo. Las perspectivas de los estudios de diásporas permiten analizar cómo éstas se imaginan sus orígenes a distancia en las relaciones políticas entre los países de destino y sus orígenes. Utilizo los estudios de turismo como segunda herramienta metodológica, no sólo porque la escena etnográfica de este trabajo es un lugar turístico para la diáspora, sino porque la perspectiva de "anfitriones y turistas" de los estudios de turismo (Smith 1977) es sugestiva y adecuada para ver la dinámica de la construcción de cultura, identidad y lugar en los encuentros entre la gente-en-movimiento y la gente inmóvil en una situación pos-colonial y para describir a la gente que no se mueve físicamente como sujetos que viven dentro del sistema político y económico mundial, no como "nativos encarcelados" en un sólo sitio.

\section{Políticas de la nostalgia}

Según el diccionario de la lengua española de Real Academia Española, la palabra nostalgia se refiere a la "pena de verse ausente de la patria o de los deudos o amigos" o "tristeza melancólica originada por el recuerdo de una dicha pérdida, añoranza". Como lo señala la traducción de este término en ingles, homesick, la nostalgia es un sentimiento relacionado con el hogar. Es la tristeza o el malestar por la causa de la distancia espacial y temporal entre el lugar, donde se encuentra el sujeto actualmente, y el hogar o el terruño, donde sus familiares y otras personas cercanas con quien compartía la vida en ese lugar que se imagina en sus memorias. Es un sentimiento de insatisfacción con la condición de su vida actual en el lugar lejano de su hogar y su gente querida, y a la vez, un anhelo por

\footnotetext{
${ }^{16}$ Roberto Alejandro, Hermeneutics, Citizenship, and the Public Sphere, Nueva York, State University of New York Press, pp.6-7, citado por García Canclini, 1995, p.32.
} 
el terruño. El imaginario es un concepto neutral, ni correcto ni negativo. Se refiere simplemente a una imagen mental. No obstante, cuando uno describe con nostalgia dicho lugar lejano en su mente, el lugar que se describe en su mente ya no es un término neutral. Con la nostalgia, uno lo idealiza, siente apego a su hogar y anhela regresar ahí para llenar la insatisfacción, en cambio, mira el lugar en donde se encuentra con un sentimiento negativo.

En esta sección, explicare diversas maneras en que se forman la nostalgia de los viajeros y el lugar espacial y temporalmente distanciado que se imaginan. La nostalgia es un sentimiento personal y subjetivo, pero, como veremos en lo siguiente, la formación de esta subjetividad tiene que ver no solamente con las experiencias individuales, sino también con los aspectos políticos y económicos del mundo que rodea al sujeto. Muchas veces, el lugar imaginario que describen los viajeros se convierten en objeto de control y se utiliza la nostalgia como un instrumento para realizar varios intereses dentro del sistema político y económico mundial.

Toni Morrison (1990), la escritora afro-americana de la literatura negra, y Salman Rushdie (1991), escritor nacido en la India y residente en Inglaterra, señalan cómo los escritores diásporas reconstruyen en sus obras sus lugares de origen. Las diásporas como minorías en la tierra extranjera viven en el sentido de pérdida: la pérdida de hogar y de pasado (Salman 1991). Lo que hacen para recuperar su pasado y su hogar es, primero, reconstruirlos en la memoria. Pero, las memorias no están completas para restituir precisamente lo que se perdió. Para complementar las memorias, ellos utilizan la imaginación. Para Morrison, este acceso al pasado y al lugar es similar a la arqueología. Se excava un sitio y se descubren los restos de la antigüedad. Para restituir este sitio a su aspecto anterior, se pegan los restos con los otros por un adhesivo de imaginación, y se reconstruye una escena del pasado. De igual manera, las diásporas excavan sus memorias y las de otras personas, y combinan unos fragmentos del pasado con otros con la imaginación, así reconstruyen el pasado y el origen. Por eso, el pasado que se recupera de esta manera no es lo mismo que lo que era realmente, el lugar que se reconstruye por las memorias parciales y la imaginación tampoco 
es lo mismo que el lugar real y actual. En este sentido, el lugar que las diásporas reconstruyen de este modo es una ficción o un lugar imaginario.

Sin embargo, las imágenes de un lugar que la gente concibe no se forman solamente por las memorias y la imaginación individuales, sino también por las influencias del mundo más amplio que rodea la vida diaria de la gente que las describe. Raymond Williams (1973), revisando varios textos de la literatura inglesa cuyo tema gira en torno a campo y ciudad, encontró ciertas imágenes persistentes. Por un lado, el "campo" nos evoca la idea de modo de vida natural, de paz, de inocencia y de virtud. Por el otro lado, la "ciudad" nos trae la idea de lugar ruidoso, de aislamiento y de hostilidad. Williams intenta analizar, históricamente, estas imágenes que se conciben en las experiencias de la vida cotidiana, e intenta describir el sistema más amplio que se expresa y se percibe sutilmente en las experiencias de la vida diaria. Señala que hay cierta tendencia permanente y común entre los textos revisados: los autores se quejaban de la desaparición de viejo y buen tiempo de Inglaterra, de la destrucción del orden tradicional del campo y de los cambios en la vida rural. Curiosamente, estas quejas aparecen en la descripción de varios libros en varias épocas. Para explicar esta persistente nostalgia, el autor utiliza el concepto de "estructura de sentimiento", que permite integrar las experiencias, personalidad y sentimientos del sujeto de estudio al sistema político y económico más amplio. Según él, los campos que los autores añoraban fueron las localidades en donde pasaron su niñez, y las descripciones, que se quejaban de los cambios en la vida rural y añoraban el pasado, aparecieron en los períodos de gran cambio en la vida urbana y la economía rural. Tomando en cuenta estos dos puntos, concluye que las imágenes idealizadas de campo y la añoranza de su niñez se han formado como respuesta de la gente a los cambios en sus experiencias cotidianas que han ocurrido en el proceso de penetración del sistema económico capitalista en la vida rural y en la urbana. Williams sostiene que nuestros sentimientos, imaginación y experiencias, en cierto grado, están definidos por las influencias del sistema que nos rodea. No obstante, como veremos en los siguientes casos, estos 
sentimientos e imaginación pueden ser objetos de control intencionado por parte de varios sectores para realizar sus intereses económicos y políticos.

Boorstin (1964) sostiene que gracias al desarrollo de los medios masivos de comunicación, los turistas pueden describir la imagen de lugar de visita antes de llegar a su destino, y critica al papel que juegan los medios masivos en la producción de imágenes. Las imágenes de destino, que se producen en gran cantidad por los medios masivos y la industria de turismo conforme a las necesidades de consumidores, enseñan a los turistas qué les va a pasar en su destino antes de visitarlo. Boorstin llama a este evento otorgado con anticipación por los medios masivos como "seudo-evento" (pseudo-event), y sostiene que los turistas visitan lugares turísticos para "reconfirmar" las imágenes hechas de antemano. Por ejemplo, los turistas suelen tomar las mismas fotos que aparecen en los folletos y las guías turísticas y quieren disfrutar del ambiente haciendo lo mismo que las estrellas hacen en la película al visitar el lugar de destino.

A igual que Boorstin, Augé (1998a;1998b) critica las influencias de imágenes que producen los medios de comunicación y la industria de turismo en la capacidad de los turistas de percibir la realidad y el lugar. Según Augé, las imágenes que nos rodean de varias formas (a través de la televisión, el Internet, la literatura y las películas) afectan nuestra vida social hasta el punto de hacernos dudar de la realidad. Estamos en una era de la "ficción total", y se está instaurando un "nuevo régimen de ficción" (1998a). En esta era de la "ficción total", todos los lugares, paisajes, escenas y personas del mundo que los turistas encuentran en sus viajes están codificados por imágenes. En este mundo ficcionalizado, los lugares turísticos se remodelan imitando el imaginario o la ficción para satisfacer la nostalgia que los visitantes describen y al mismo tiempo, para producir nuevas imágenes. Los turistas hacen turismo para consumir las imágenes o los estilos de vida que esos lugares, revestidos por los signos, les ofrecen (Stewart 1988), y toman fotos "para poder decir que he estado allí y para dar la prueba de ello" (Augé 1998b:26) y para fabricar imágenes que puedan inspirar el imaginario de los demás. Por eso, las miradas de los turistas y la realidad que ellos observan están controladas y limitadas por imágenes. Aunque cabría diferir en algunos puntos de 
la discusión de Augé, ${ }^{17}$ lo que quiero destacar aquí es que el lugar imaginario que los turistas describen no es un simple producto de su imaginación individual. De cierto grado, el lugar imaginario se alimenta por las imágenes que producen los medios de comunicación y la industria de turismo. No obstante, como veremos en los siguientes casos, la producción de las imágenes no se limita solamente a los terrenos económicos. A veces, la producción de nostalgia e imágenes de lugar también puede ser un proyecto político.

Jennifer Robertson (1991) analiza las imágenes que evoca la palabra furusato, una palabra repetida y ubicua en varios contextos en Japón en los años ochenta. Furusato se traduce como "vieja aldea", "terruño" y "tierra natal". El paisaje de furusato se asocia con las montañas con bosques, los campos atravesados por el río y las casas campesinas con techo de paja. También evoca un estilo de vida estético y rústico y la imagen de un lugar donde hay confianza y dependencia entre vecinos y el amor de la madre. Según Robertson, estas imágenes de furusato se han formado por un proyecto de la construcción del Estado-nación y han sido apropiado por los japoneses como nostalgia del "paisaje original" de Japón y como imágenes dominantes de la nación.

Por la rápida urbanización y industrialización y la internacionalización del país desde el período de posguerra, los japoneses han vivido el sentido de perdida de hogar adonde poder regresar. Este hogar son regiones rurales de donde la mayor parte de la población ha salido a las zonas urbanas y donde el modo de vida estaba vinculado estrechamente con la agricultura. Los paisajes de terruño para los habitantes de ciudades han cambiado y destruido por la contaminación

17 A igual que Boorstin, Augé (1988b) considera que los turistas viajan para reconfirmar las imágenes. Sí, es cierto que en el caso del turismo masivo, al observar sus comportamientos (por ejemplo, su manera de filmar y fotografiar), parece que ellos actúan conforme a lo que dice la guía o lo que hacen los personajes de una película grabada en ese lugar. Pero, hay turistas que no pueden estar satisfechos con hacer simplemente reconfirmación y que intentan ver lo que hay detrás de la escena decorada por imágenes para la búsqueda de "autenticidad" (MacCannell, Dean 1973). Otra crítica que se puede agregar es que Augé considera que en las épocas anteriores, los viajeros europeos hacían viajes de descubrimiento, viajes que hoy en día ya son imposibles. Pero, en esas épocas, los viajes no necesariamente estaban libres de imágenes y nostalgia que ellos describían hacia los lugares aún desconocidos. Véase Pratt (1992). Yo no estoy de acuerdo con Augé (1998b) en la idea de "viaje imposible". Su enfoque radica solamente en la observación de los comportamientos de los turistas (sin entrevistas profundas con éstos). Discutiré este punto después de la sección siguiente. 
ambiental y la urbanización de muchas regiones rurales. Además, el modo de vida tradicional también se ha modificado en los procesos de la internacionalización. Por consecuencia, ya no existe ningún lugar que los japoneses pudieran considerar como su hogar y su terruño en donde las madres se encargaban de la cría de niños, las familias se componían de tres generaciones y los habitantes urbanos pasaban su niñez entre la naturaleza y el paisaje de campos de arroz. Ya no hay ningún lugar particular para sentir nostalgia. A pesar del rápido crecimiento de la economía del país, se han difundido una perspectiva pesimista sobre el futuro de la sociedad y los japoneses han vivido una nostalgia por la experiencia de la nostalgia. En este contexto, el proyecto nacional de furusato-zukuri (reconstrucción de furusato) se puso en marcha por el Partido Liberal Demócrático en 1984 como un proyecto administrativo para forjar una nueva cultura nacional. En este proyecto nacional de la reificación de furusato se involucran varios sectores: varias organizaciones gubernamentales nacionales y locales, grupos ambientalistas, grupos de estudio localistas, los migrantes internos y los nativos. Además, la palabra furusato se usa en las canciones populares y los anuncios de sake, y las imágenes de furusato, que inspiran el paisaje de nostalgia, se encuentran ubicuas y repetidas en todo el país.

En 1984 se inauguró el Festival de Furusato Tokio para animar a los residentes en Tokio a regresar metafóricamente a su nuevo terruño, Furusato Tokio. Sin embargo, en el nivel local, la introducción del proyecto de furusatozukuri no se limita solamente a ciudades. Este proyecto también fue aplicado a los pueblos rurales como una estrategia para desalentar la despoblación y buscar una nueva fuente de recursos económicos que pudiera substituir a la agricultura. Varias regiones rurales que sufren de despoblación se promueven como furusatomura (pueblos de "vieja aldea") para atraer a los turistas que salen de las zonas urbanas en las temporadas de vacaciones como "habitantes honorarios del pueblo". En 1985 se fundó el Centro de Información Furusato en Tokio por el apoyo del Ministerio de Agricultura, Forestal y Pesca para facilitar la rehabilitación de las regiones rurales despobladas a través de la creación de redes entre ciudades y campos. Este organismo juega el papel de distribuir folletos, revistas y 
guías y realizar investigación sobre imágenes de furusato. Además, Ferrocarriles Nacionales de Japón empezó una campaña llamada Discovery Japan en los setenta y otra campaña llamada Exotic Japan en los ochenta para impulsar a los habitantes de ciudades a viajar dentro de los territorios nacionales. Las conexiones entre furusato en regiones rurales y ciudades también se han fortalecido por el servicio del envío de paquete furusato, inaugurado en 1985 por el Ministerio de Servicios Postales, que facilita a aquellas personas que no pueden viajar a las provincias conseguir los productos típicos de cada región a través de la oficina del servicio de correo cercano.

Al visitar furusato-mura, los turistas se quedan un largo tiempo disfrutando de la recolección de hongos y del cultivo de arroz en la forma tradicional (aunque los nativos del pueblo ya no viven de este modo de vida ni los visitantes tampoco, en realidad, dependen de la agricultura para vivir durante su estancia). Lo que experimentan ambas categorías de personas no es una vida real de pueblo, sino una vida semejante a la vida de pueblo, una vida "exotizada" de terruño como si fuera ese lugar en realidad "nuevo hogar" o "nuevo furusato" de los turistas. Por eso, el furusato-mura es un lugar reconstruido para que los visitantes puedan imaginarse su hogar y furusato. Furusato-zukuri no es un proyecto del gobierno para forzar a regresar a una economía agraria y una forma de vida tradicional que en el pasado existía realmente, sino que es un proyecto de crear en el país entero un ambiente que se pueda sentir como "tradicional" y como su terruño tanto en las regiones rurales como en las ciudades que se encuentran en los procesos de la modernización. Como la palabra Furusato Tokio muestra, aquí, la modernidad y la tradición no son nociones incompatibles. En resumen, furusato-zukuri es un proyecto para regular la imaginación de la Nación y una empresa de la reificación de un terruño imaginario e ideal adonde los japoneses que viven el sentido de perdida de hogar puedan regresar y satisfacer su nostalgia por la nostalgia.

Robertson analizó cómo el Estado japonés se ha intentado transformar en una comunidad imaginada nacional (Anderson 1983) o una nación hiperreal que pueda ser llamada hogar para todo el pueblo en los procesos de la internacionalización, la urbanización y la industrialización a través de la fabricación 
y la difusión de las imágenes de furusato y la reificación de ello. En el caso de la reconstrucción de furusato, las imágenes de furusato y la nostalgia son instrumentos políticos y económicos, y el lugar imaginario para los japoneses se ha reinscrito por los discursos del Estado y de las políticas locales y por paisajes reconstruidos conforme a las imágenes del terruño que representa el Estado para dar al pueblo una nueva imaginería de la Nación. Sin embargo, a medida que hoy en día circulan la gente, dinero, objetos e información en todo el planeta con gran rapidez, atravesando las fronteras nacionales, la forma en que se imaginan las comunidades, en algunos casos, va más allá de las fronteras nacionales.

Anderson desarrolla su idea de comunidades imaginadas en su artículo, The New World Disorder (1992). Según Anderson, el desarrollo de los medios de transporte de larga distancia (tren, autobús y avión) con rapidez y seguridad y el de la tecnología de comunicación (telex, teléfono, correo e internet) no sólo han incrementado la velocidad y la escala de los flujos migratorios transnacionales, sino que también han facilitado a los migrantes que se encuentran lejos de sus terruños los contactos reales e imaginarios con sus orígenes. La facilidad de moverse entre asentamientos y lugares de origen, comunicarse con sus familiares en sus pueblos y conseguir los productos de sus países de origen, que evocan las imágenes del terruño, dificultan que los migrantes se incorporen a los países anfitriones según el modelo de asimilación y que los países receptores se formen como comunidades imaginadas monolingúísticas, monoreligiosas y monoétnicas. En cambio, estas facilidades permiten a las diásporas construir los espacios sociales y culturales en donde pueden imaginar sus raíces y mantener conexiones con sus terruños. En otras palabras, se han formado comunidades imaginadas que atraviesan las fronteras nacionales y mantienen los vínculos entre los asentamientos y los lugares de origen a través de la migración masiva y la circulación de bienes e información.

En estas comunidades imaginadas "reterritorializadas" (Gupta y Ferguson 1999:37), los objetos que circulan entre países receptores y países emisores juegan un papel importante para la formación del lugar imaginario que describen los migrantes. Como explica Boruchoff (1999), los objetos culturales derivados del 
lugar de origen representan su terruño para los migrantes que se encuentran lejos de su terruño real. El lugar representado por los objetos les recuerdan sus experiencias en su terruño real, les inspiran añoranza y alimentan su imaginación. Por ejemplo, una tarjeta postal del Partenón producida por Lufthansa que está pegada en la pared del departamento de un migrante griego en Stuttgart, Alemania. Esta Grecia de la tarjeta postal no es la memoria real de este migrante. Es un lugar de representación creado por algún fotógrafo. Pero, al mismo tiempo, esta imagen de la postal es un signo de "Grecia", es decir, para este migrante griego, es un lugar imaginable (Anderson 1992:9).

Sin embargo, en el contexto en que las diásporas se imaginan las comunidades y sus orígenes sin importando las fronteras nacionales, en ocasiones, su imaginación y el sueño de regresar al origen se controlan por los factores económicos. Paulla A. Ebron (2000) analiza el tour de la diáspora negra en Estados Unidos a Senegal y Gambia, organizado por McDonald's con la participación de una agencia de publicidad, la familia de Alex Haley, el autor de Roots (1976), en el cual se basa la telenovela Roots, y los ganadores del concurso patrocinado por McDonal's como parte de campaña comercial durante el Mes de la Historia Afro-americana (African American History Mounth) en 1994. No sólo McDonal's la compañía que hace real el mito de retorno de la diáspora negra a "Madre África". En 1998 Heineken promovió un viaje a Ghana durante dicha temporada dedicada a la historia afro-americana. Este caso del retorno muestra que se vende el sueño de la diáspora negra de regresar a su origen con los productos de las compañías o más bien las compañías producen las imágenes de "Madre África", domestican los sueños sobre el origen e inspiran a los consumidores diaspóricos la nostalgia hacia "África" para promover la venta de la hamburguesa y la cerveza (Ebron 2000:927).

Por otra parte, en las comunidades que se imaginan más allá de las fronteras nacionales, la formación del lugar imaginario y de la nostalgia también tiene aspectos políticos. Según Safran (1991), el mito de origen de la diáspora se construye en las relaciones entre la diáspora, la sociedad receptora y el país de origen. En algunas veces, este mito se manipula y se crea como instrumento para 
la negociación política en esta relación triangular. Por ejemplo, en el caso de los turcos en Alemania, un resultado de una encuesta de la opinión pública de los turcos muestra que más de la mitad de los entrevistados tiene el deseo de regresar a Turquía dentro de unos años (los que tenían el plan de quedarse en Alemania permanentemente fueron solamente cinco por ciento). Para Safran, esta actitud de los turcos hacia su terruño representa, hasta cierto punto, "una internalización del 'mito de retorno' (Heimkehrillusion) que se fomenta asiduamente por las elites y los políticos alemanes, quienes temen una inundación del país por extranjeros (Uberfremdung) y quienes insisten en que Alemania no es un país de inmigrantes" (86).

Asimismo, los países de origen de los migrantes también estimulan el retorno a sus orígenes. Por ejemplo, al impulsar a los filipinos que han salido del país a visitar su patria una vez al año durante los días festivos, el presidente Marcos de Filipinas creó el término balikbayan (en español, retornados, en inglés homecomers) y permitió a cada uno de los retornados traer al país al año dos cajas de balikbayan, que tienen dentro las mercancías extranjeras como regalos, con impuestos menores. Esta política hacia los migrantes filipinos fue heredada en el régimen político de Aquino, y tanto los flujos de los migrantes como los de objetos y remesas, que son muy importantes para la economía de Filipinas, han sido institucionalizados por la nación filipina (Glick Schiller et al. 1992a:3-4).

Otro ejemplo de la relación entre el origen y la diáspora es el caso del retorno de los jóvenes miembros de las comunidades transnacionales chinas en el extranjero. En 1982 el gobierno de la Republica Popular de China empezó a patrocinar un festival juvenil para promover la visita de los jóvenes descendientes chinos que son ciudadanos de otros países. Este festival juvenil es un ritual político del Estado chino a través del cual el Estado intenta promover entre los jóvenes miembros de la diáspora china una nueva identidad china que hace énfasis en la asociación natural entre rasgos físicos (cabello negro, piel amarilla y ojos negros), cultura y nación. Lo que busca el gobierno promoviendo esta nueva identidad es crear conexiones entre el Estado chino y las comunidades 
transnacionales chinas para la construcción de una nación moderna bajo la política de reapertura y reforma económica (Louie 2000).

Algo similar pasa entre los migrantes mexicanos en Estados Unidos y el gobierno de México. En los años recientes, el Estado mexicano ha modificado el concepto de "mexicanidad". Se autopercibe como un país "multicultural" y reconoce como componentes del Estado multicultural las diferencias culturales de los grupos étnicos y sociales que antes estaban excluidos de la categoría de "mexicano" y discriminados por sus diferencias.

En esta línea de las políticas del Estado mexicano post-nacional, los mexicanos en el extranjero, sobre todo en Estados Unidos y sus descendientes nacidos en ese país se considera como diáspora mexicana que forma parte del Estado (González Gutiérrez 1999), y se ha intentado cultivar una relación estrecha y de largo plazo entre el Estado mexicano y la diáspora en Estados Unidos ante el gran crecimiento de la migración a ese país. Hay varias razones por las cuales le ha interesado al Estado mexicano fortalecer el vínculo con las comunidades diaspóricas en ese país. La primera es porque una estrecha relación con la diáspora puede constituir un mercado extraordinario para las exportaciones de productos nacionales; la segunda es porque las remesas que los migrantes envían a sus familiares desde Estados Unidos son una fuente muy importante de moneda extranjera ${ }^{18}$; además, el fortalecimiento de la comunicación con las comunidades diaspóricas mexicanas permite crear una base para defender los derechos humanos de los mexicanos en el extranjero y por último, un acercamiento a estos grupos étnicos, que da una gran influencia en el proceso de toma de decisiones en la política estadounidense, puede beneficiar al Estado mexicano en las negociaciones de política exterior (González Gutiérrez 1999).

En 1990, esta nueva política del Estado hacia la diáspora se encarnó en el Programa para las Comunidades Mexicanas en el Extranjero cuyo objetivo

\footnotetext{
${ }^{18} \mathrm{Em} \mathrm{2001}$, la suma de los recursos que los mexicanos en el extranjero enviaron a sus familiares en México alcanzó a 8,895 millones de dólares (en 2000, 6.5 mil millones). Este monto de las remesas es equivalente a 69.5 por ciento del valor de las exportaciones petroleras. En cuanto a la distribución de las remesas familiares por entidad federativa de destino, Michoacán fue el estado que recibió la mayor cantidad de estos recursos (11.7 por ciento del total de las remesas), Guanajuato fue el segundo lugar (8.9 por ciento), y Jalisco, el tercero (7.9 por ciento) (Banco de México 2002).
} 
principal es "levantar conciencia entre los mexicanos de todo el mundo que la 'Nación mexicana rebasa el territorio que contienen sus fronteras' (Presidencia de la Republica 1995) e instrumentar la oferta de cooperación internacional de México para beneficio de los mexicanos de origen que viven en el extranjero, principalmente en los Estados Unidos" (González Gutiérrez 1999:271-272). Aparte de este programa, el gobierno mexicano estableció en 1989 el Programa Paisano con la participación de varias organizaciones gubernamentales para promover el retorno de los mexicanos establecidos en el extranjero.

En pocas palabras, el Estado intenta impulsar a la diáspora a adquirir conciencia de ser mexicanos y regresar a su origen. Al promover el mito de origen y el de retorno, la nación emisora está intentando expandir su dominio e influencias más allá de las fronteras nacionales.

Hasta aquí he explicado como se forman la nostalgia y el lugar imaginario desde el nivel individual hasta el transnacional, considerando como sujetos de estudio las personas que literalmente viajan de un lugar a otro. Por un lado, el lugar imaginario se construye en las memorias y la imaginación individual. Por el otro, el imaginario también se nutre por el lugar de representación, o sea, el lugar que se representa en las imágenes como símbolos. En lo siguiente, veremos cómo la materialización del lugar imaginario que se forma de estos modos influye sobre el lugar real, centrando el enfoque en los puntos de vista de la gente que recibe a los viajeros para ver la dinámica de la creación de lugar, cultura e identidad en las zonas de contacto. ${ }^{19}$

\section{Apropiación cultural y resistencia a las imágenes en el turismo}

Las imágenes de lugar que se producen de esta manera influyen sobre la realidad en el lugar que recibe a los turistas. Para que la realidad en ese lugar no defraude la expectativa de los turistas, la ficción tiene que convertirse en la realidad, y el lugar debe reconstruirse conforme al lugar imaginario que los visitantes conciben,

\footnotetext{
${ }^{19}$ Esta idea sobre la relación entre el lugar imaginario, el lugar de representación y el lugar real fue inspirada por el seminario de Federico Besserer, "Comunidades transnacionales y diásporas: Una aproximación antropológica", el curso de Temas Selectos en Antropología Económica 1 de Trimestre: Invierno 2001 para la licenciatura de Departamento de Antropología de la UAMIztapalapa.
} 
es decir, se requiere la creación de la hiperrealidad. El paisaje del lugar de visita se remodela, y algunas tradiciones se modifican e incluso se "inventan" de tal forma en que la cultura de ese lugar represente las imágenes que los turistas quieren reconfirmar (Hobsbawm y Ranger 1983).

Por ejemplo, en Bali, Indonesia, hay una danza que se llama quecha. Para los turistas, es conocida como la danza de mono (monky dance). Aunque ellos creen que esta danza es una tradición de Bali, en realidad esta danza se inventó por un pintor alemán en los años treinta para grabar una escena de la película y atraer a los turistas (Yamashita 1996).

Wai-teng (1989) analiza el papel que juega el Estado en la formación de cultura en el turismo en Singapur. Para los países recientemente independizados, como Singapur, que tienen diversos grupos étnicos, la construcción de la cultura nacional es la preocupación central del Estado para construir una identidad nacional como base para unificar los diversos grupos sociales y étnicos. En este contexto, el turismo nacional es un proyecto ideal que persigue el desarrollo económico y la construcción de la cultura nacional a la vez. Al crear una nueva cultura nacional, el Estado selecciona y manufactura ciertas imágenes del país y tradiciones para presentar como "patrimonios nacionales" o "tradiciones nacionales" al mercado internacional. La imagen principal del turismo nacional en Singapur es la diversidad de "tradiciones" étnicas. Los folletos y las guías oficiales de la organización nacional de turismo aseguran que en Singapur las "tradiciones" de diferentes grupos étnicos siguen existiendo y conservándose en la metrópoli con armonía. Las "tradiciones" que se presentan oficialmente son de cuatro categorías ("chinos", "malayos", "indios" y otro) a pesar de que en realidad hay distintos grupos étnicos dentro de cada categoría. La mayoría de atracciones y sitios turísticos se presentan por esta clasificación étnica que el Estado heredó del gobierno colonial. En suma, el Estado selecciona los grupos étnicos y las tradiciones "representables" y manipula la diversidad de estilo de vida, costumbres, comida y rituales que realmente existen dentro del país para manufacturar las "tradiciones nacionales" y la "cultura nacional" de Singapur. Lo mismo pasa en el proyecto de la reconstrucción de furusato en Japón. Al recibir a 
los habitantes honorarios, en algunos furusato-mura se han inventado, reinventado o revivido varias actividades "tradicionales" de pueblo. Entre ellas, hay kagura, que es la música y la danza shintoista que se practica en el templo (Robertson 1991:31).

Como estos casos muestran, los Estados y la industria de turismo modifican, falsifican y fabrican el paisaje, las culturas y las tradiciones, incluso inventan la "etnia" para que la realidad de los lugares coincida con las imágenes. Se combinan las cosas reales, los originales y las tradiciones que había existido con lo falso, lo ficticio y lo inventado. Los componentes de este bricolaje son los signos de lo real y lo exótico. En este sentido, al reificar la nostalgia hegemónica, es decir, la nostalgia que describen hacia los lugares los turistas y los administradores del turismo, las culturas y las tradiciones locales se convierten en simulacros, incluso en las mercancías que se les venden a los turistas para satisfacer su deseo de consumir la nostalgia hacia cierto estilo de vida y lo exótico. $^{20}$

Sin embargo, la reconstrucción hiperrealista de lugar y cultura provoca diversas formas de reacción de los anfitriones. Algunos sectores de las sociedades anfitrionas se apropian de la nostalgia hegemónica y definen como "propias" y "auténticas" las culturas construidas por y para los "otros". Pero, no todos los sectores de lugares turísticos son consumidores dóciles ni son actores sometidos al guión de la nostalgia hegemónica. Por ejemplo, Quetzil Castaneda (1995;1996), quien analiza la invención de la cultura maya, describe la actitud que muestran los mayas hacia esta cultura. Argumenta que la invención de lo maya como una cultura se ha realizado con las complicidades históricas entre los mayas, las prácticas antropológicas, la industria de turismo, las políticas regionales del estado de Yucatán, las políticas nacionales de México, los espiritualistas del grupo New Age y los turistas (Castañeda 1996). Por ejemplo, el evento del Equinoccio en Chichén Itzá fue inventado para reinventar la cosmología

\footnotetext{
${ }^{20}$ Mason sostiene que lo exótico "no es algo que existe antes de su 'descubrimiento'. No es una noción a priori, sino una construcción histórica y cultural. Para él, "lo que produce lo exótico como tal es el acto de descubrimiento en si", y lo exótico siempre está abierto para contestación, renegociación y reinvención (Mason 1998.1-2.)
} 
maya. Sin embargo, la cultura maya que se representa, a través de las prácticas rituales de este evento, por los arqueólogos, los guías, los turistas y los espiritualistas no es la cultura maya actual, sino la cultura maya antigua. En este sentido, este evento se basa en la exclusión de los mayas actuales. La actitud que adoptan hacia el evento del Equinoccio los mayas del pueblo cercano a esta zona arqueológica es indiferente, como si esta cultura maya les fuera algo ajeno. Aprovechan esta fecha en la que miles de turistas visitan la pirámide para vender artesanía de su pueblo y de otros estados.

Sin embargo, hay ocasiones en que el turismo provoca reacciones más fuertes de algunos sectores de los anfitriones. Por ejemplo, se puede interpretar el turismo como destrucción no solamente de la naturaleza y los paisajes por la explotación, sino también de la cultura local y las tradiciones que se han practicado entre los lugareños antes de la llegada de los turistas (Greenwood 1977). Además, las imágenes sobre el lugar y la gente que vive en ese lugar producidas por los medios masivos se pueden tomar como estereotipos o prejuicios contra ellos. Para los habitantes de la sociedad anfitriona, algunas veces, la situación en que las imágenes que se les imponen por los "otros" forman y definen la cultura local es una experiencia tan humillante que los locales intentan resistir a las imágenes para recuperar su propio lugar y su propia identidad. Por ejemplo, en Hawaii, los activistas del movimiento indígena critican las imágenes de Hawaii producidas por los medios de comunicación y la industria de turismo, tales como la imagen de "paraíso Hawaii" y de lugar en donde las indígenas sensuales y medio desnudas reciben a los turistas, y para resistir a este tipo de estereotipo han desarrollado un movimiento anti-turismo y revisan las descripciones sobre los indígenas de Hawaii en publicaciones a través de las redes internacionales que tienen.

Otro ejemplo de la resistencia cultural en el turismo procede de la punta de la costa norte de Long Island, donde está una villa que se llama Orient (Stewart 1988). La gente que viene de la ciudad ha llamado esta villa "nueva tierra". Los recién llegados han construido casas de estilo "rural" y han convertido ésta en una villa imaginaria de Nueva Inglaterra del siglo XVIII. Esta explotación de terreno 
para viviendas ha pintado una nueva imagen - la época del siglo XVIII- en esta localidad para satisfacer la nostalgia de los nuevos poblados. Sin embargo, los "locales", quienes han vivido en este lugar desde antes, adscriben a esta nueva imagen un significado diferente: "la época del siglo XVIII" que representa esta villa remodelada no es su propia historia. Para ellos, la reconstrucción del lugar por los signos de "la época del siglo XVIII" es una invasión simbólica que borra la historia, y las memorias que los "locales" habían inscrito en esta localidad. Además, la explotación de la villa les quita, "manchando" con otros signos, los espacios en donde van a inscribir su historia en adelante. Pero, ellos no responden a la nostalgia de "otros" pasivamente, sino que la resisten e intentan reinscribir sus propios significados sobre la nueva imagen. En vez de colaborar en los esfuerzos para crear la apariencia de la villa del "siglo XVIII", dejan los objetos "inadecuados" para esta imagen en sus jardines e inscriben, a propósito, graffiti y signos "inadecuados" encima de la apariencia que representa esta imagen. De esta manera, impiden que su localidad esté completamente codificada por la mirada de "otros".

En suma, se puede decir que el turismo que reconstruye el lugar y la cultura local conforme a la nostalgia que los turistas conciben hacia el lugar y la gente, a veces se interpreta como una conquista que les quita a los habitantes un lugar propio y una cultura propia a través de la "pavimentación" de nuevos signos. La "cultura" que se representa en el turismo recubre el lugar, tradiciones y culturas locales con un color teñido por la nostalgia que se produce para los turistas. Relega a los lugareños, que no pueden identificarse con sus imágenes, a los márgenes de la escena del turismo, incluso los convierte en "minoritarios culturales". La "cultura" construida por la nostalgia para los dominantes en el turismo, tiene una característica muy similar al concepto de "cultura" antropológica convencional: se aplica al grupo entero, la comunidad o el país en conjunto la descripción sobre algunas costumbres y escenas del campo observadas y la narración de algunas personas grabada en una situación. "Confinan" a los nativos en ciertas imágenes y en un mundo etnográfico (Appadurai 1988b). 
Sin embargo, paradójicamente, la gente que depende del turismo económicamente no puede negar por completo las imágenes que se producen en el turismo. A lo que se tiene que prestar atención aquí es que el turismo está constituido basándose en una relación de poder inequitativa entre los anfitriones y los turistas y entre los habitantes de lugares turísticos y los sectores que promueven el turismo, y que la reconstrucción del lugar y la cultura, dando prioridad a las imágenes que los turistas conciben, es un ejercicio de poder. Si el turismo es un fenómeno inevitable para la sociedad anfitriona, lo importante es ver cómo la gente resiste a este ejercicio de poder y busca los espacios en donde pueda representar sus identidades y sus propios terruños imaginarios dentro del contexto del turismo (Ota 1993). Presentaré, ahora, algunos casos que muestran cómo algunos sectores de los anfitriones intentan recuperar sus propios lugares en los procesos de la reificación de lugares imaginarios para los sectores dominantes en relaciones de poder. Aquí, las palabras claves, son negociación, ductilidad e hibridación.

Los ainu son un grupo indígena que vive principalmente en Hokkaido, y al mismo tiempo es uno de los más grupos marginados y discriminados en Japón. En el pasado los ainu eran el objeto de turismo en Hokkaido y se presentaba en el turismo como grupo étnico exótico que se supone que aún conserva su modo de vida y cultura "primitivos" y diferentes que la vida de los demás japoneses en un país moderno. Pero, ahora ellos participan en el turismo como sujetos y utilizan el turismo como un instrumento para cambiar estereotipos y prejuicios en su contra que han existido en Japón. También lo utilizan para representar su cultura por sus propias manos, los modos de representación y los medios de comunicación de la sociedad japonesa que los ha discriminado. Construyeron el museo y casas tradicionales (chise) para presentar rituales e historias de vida de algunos miembros a los turistas y para enseñarles cómo se producen las artesanías. Ponen anuncios en periódicos la fecha y el horario de la presentación de rituales para invitar a los japoneses (wajin) a visitarlos. Incluso invitan a estudiantes extranjeros en las universidades en Hokkaido (Ota 1993). En este caso, "el turismo 
es una arena importante en la que los ainu puedan reclamar su propia identidad étnica en una sociedad que les ha negado una oportunidad para formularla"(409).

"Nosotros también tenemos que vivir en esta sociedad japonesa. Por eso, tenemos que ampliar nuestro espacio para sobrevivir. Si no, vamos a ser eliminados completamente, y unos pocos sobrevivientes van estar exhibidos más que ahora como grupo en extinción y exótico" (Narita 1985:252).

El anterior es un comentario que hizo un miembro de los ainu en una negociación con una agencia de turismo que publicó un anuncio muy discriminatorio en el periódico Japan Times en 1981. Lo que esta persona estaba reclamando no era la negación del turismo ni de la sociedad japonesa, sino que se puede interpretar como una reclamación contra el turismo que niega su subjetividad y su participación en la producción de las imágenes de los ainu. Años después de esta negociación, ellos han construido una escena desde donde puedan emitir sus nuevas imágenes a la sociedad japonesa como he descrito. No obstante, la apropiación cultural dúctil, no dócil, de la escena preparada para satisfacer la nostalgia de los dominantes no sólo es privilegio de los ainu. ${ }^{21}$

Esta estrategia para la negociación de identidad también se utiliza en otra situación pos-colonial en la sociedad japonesa que ha marginado a este grupo étnico. La etnografía de Robertson (1991), Native and Newcomer, muestra cómo una ciudad se reconstruye y se transforma en "terruño" tanto para los lugareños como para los migrantes internos que han radicado en ese lugar recientemente en los procesos de la urbanización y del proyecto nacional furusato-zukuri. La ciudad Kodaira, que se encuentra en áreas suburbanas de Tokio, antes era una aldea agrícola construida a mediados del siglo XVII. Desde los años cincuenta la población aumentó rápidamente debido a la afluencia de los recién llegados (newcomers), y desde los años setenta Kodaira se ha transformado en una ciudad que tiene alrededor de 153,000 habitantes. Los descendientes de los pioneros

\footnotetext{
${ }^{21}$ En las situaciones pos-coloniales en las cuales la representación de identidad de los sujetos ha sido limitada por las imágenes sobre ellos construidas por los dominantes, hay muchos casos de este tipo de apropiación e hibridación cultural. Por ejemplo, los kayapo representan su cultura ante la sociedad brasileña a través de las imágenes que ellos mismo graban por la cámara de video (Turner 1992:12). También véanse Néstor García Canclini 1995, p. 153, 170.
} 
habitantes que construyeron Kodaira en el siglo XVII siguen viviendo allí y constituyen un sector nativo que representó apenas el $1 \%$ de la población de la ciudad en 1985. Los recién llegados los conforman aquellos individuos y familias de sector oficinistas y sector obrero que llegaron a Kodaira con los procesos de la urbanización y la industrialización. Esta ciudad adoptó el proyecto de furusatozukuri para crear un ambiente que los recién llegados pudieran sentir como terruño. Este sector de Kodaira fue animado a adoptar el "espíritu de pioneros" como los pioneros de hace trescientos años y a considerarse como locales por los administradores y los agentes del proyecto. Esto provocó conflictos entre los nativos y los nuevos locales. Los nativos empezaron a reclamar un lugar especial para ellos dentro de la ciudad. La antinomia entre nativos y recién llegados se manifiesta en patrones de establecimientos, festivales, prácticas rituales y asociaciones de vecinos. Robertson sostiene que Furusato Kodaira se construye a través de los conflictos y la antinomia entre nativos y recién llegados y por la apropiación contendida de furusato. En 1976 se inauguró Kodaira Civil Festival para dar una autenticidad a Furusato Kodaira. En el festival se manifiestan interpretaciones nostálgicas de vida del pueblo y rituales en siglos pasados. En este festival, la carga del mikoshi (relicario) en la procesión está encargada exclusivamente a los nativos. Los nativos reclaman su lugar en el suburbio a través de esta práctica religiosa cuyo acceso no está permitido a los nuevos habitantes. Lo importante aquí es que los nativos manifiestan su identidad, papeles y espacios propios participando con los recién llegados en el evento que forma parte de la construcción de furusato. Lo que ellos reclaman no es la recuperación total de Kodaira en sus manos ni la exclusión de los recién llegados de su tierra. De alguna manera, ellos se apropian de Furusato Kodaira como un terruño imaginario tanto para los demás habitantes como para los administradores locales del proyecto de furusato-zukuri. Participando en este proyecto, intentan buscar los medios de modificar la combinación de los signos para que ellos también puedan considerar su furusato el lugar que se reconstruye.

\section{¿El viaje imposible?}


En las políticas de la creación de hiperrealidad en el turismo y en el proyecto de furusato-zukuri en Japón, "la forma de hegemonía descansa en el modo de manejar signos de estilo y período, la habilidad de leer/construir 'códigos de distinción"' (Stewart 1988:232). Como hemos visto en la sección anterior y ésta, los lugares de destino y la capacidad de los viajeros de ver la realidad están colonizados por las imágenes a través de las cuales se ejerce el poder.

Puede plantearse la cuestión de la amenaza que hace pesar sobre lo imaginario la "ficcionalización" sistemática de que es objeto el mundo. Y esta operación depende ella misma de una relación de fuerzas muy concreta, muy perceptible, pero cuyos términos no son fáciles de identificar. Para decirlo brevemente, todos nosotros tenemos la sensación de estar colonizados, pero sin saber precisamente por quién; el enemigo no es fácilmente identificable y nosotros aventuraremos la hipótesis de que esa sensación está hoy presente en todas partes, en todo la Tierra, hasta en los Estados Unidos (Augé 1998a:19).

En otro libro, El viaje imposible: El turismo y sus imágenes, Augé sostiene que hoy en día es imposible el viaje que "habría podido abrirnos el espacio de nuevos encuentros" y que la diversidad del mundo "poco tiene que ver con el calidoscopio ilusorio del turismo"(1998b:15,16). Sin embargo, en este "nuevo régimen de la ficción" (Augé 1998a) en el que se esconde una relación económica y de poder inequitativa, todavía es posible viajar para buscar el espacio de nuevos encuentros, la diversidad cultural y algo más de lo que nos dice de antemano antes de llegar a los destinos la industria de turismo, incluso es posible en el turismo.

Como muestran el caso de los ainu y el de los nativos de Kodaira, quienes fueron relegados a los márgenes de lugares imaginarios dominantes también manejan signos y leen y construyen códigos para dar a los demás sus nuevas imágenes en las cuales puedan identificarse a ellos mismos. Lo que intentan los nativos de Kodaira y los ainu, cargando el mikoshi (relicario) en el festival e invitando a los turistas a su museo y sus rituales es reinscribir encima de las imágenes inscritas por los otros los signos de su existencia dentro de los lugares que se están reconstruyendo y han sido reconstruido por la nostalgia hegemónica. 
Es cierto que ellos también hacen el bricolaje de los signos y producen las imágenes a través de las cuales reconstruyen y representan los lugares y las culturas locales. Entonces, ¿son falsas y engañosas las culturas que se representan en esta forma? La respuesta es NO. La razón no es sólo porque en el espacio hiperreal, el imaginario y lo falso llegan a confundirse con lo real, sino también porque definir como "inauténticas" las culturas que crean los sujetos, que tratan de buscar, apropiándose de los modos de representación de los dominantes, algunos medios para sobrevivir y cambiar sus situaciones subalternas, es la negación de su subjetividad, incluso esta idea cierra la posibilidad de que los subalternos puedan salir de los márgenes de la sociedad (Ota 1993:388). Por eso, se requiere redefinir el concepto de cultura antropológica.

Si se definiera cultura en términos de "pureza" y "campo", un espacio con límites absolutos con el exterior, a medida que los "nativos" están vinculados con los mundos exteriores y se apropian de los modos de representación producidos en el exterior, la "cultura" iría extinguiéndose. Según esta forma narrativa "entrópica" de cultura, la hibridación y la apropiación cultural se entienden en términos de "inautenticidad". En cambio, al repensar el concepto de cultura en términos de coexistencia, hibridación, negociación y viaje, es posible elaborar una forma narrativa de cultura que nos permita estudiar los procesos de "surgimiento" de cultura sin caer en la dicotomía de "lo auténtico/lo inauténtico" y de "lo falso/lo verdadero" (Clifford 1988).

Los turistas viajan para llegar a los lugares imaginarios y satisfacer su nostalgia. Pero los nativos de las sociedades anfitrionas también. Cuando pierden sus lugares por la nueva codificación de signos, también experimentan nostalgia y se imaginan los lugares que puedan llamar terruños. Los nativos de los lugares turísticos son "viajeros-en-residencia", no sólo porque las conexiones simbólicas, económicas y políticas que tienen esos lugares con otros sitios les permiten vivir dentro de un contexto global, sino también porque ellos les adscriben diferentes significados a las imágenes de sus lugares producidas en el exterior y describen y buscan sus propios terruños imaginarios apropiándose de, alguna manera, los modos de representación de los dominantes y combinándolos con los suyos. Para 
ellos, reconstruir el terruño significa buscar, en su hogar codificado por los signos de lo real para los otros, los espacios donde puedan representar sus identidades. Es un intento de llegar a un lugar que satisfaga su nostalgia. Es una búsqueda de otra hiperrealidad o un "viaje" al terruño imaginario.

A través de la circulación intensa y veloz de imágenes entre varios lugares interconectados a nivel global, las culturas locales y las identidades no van homogeneizándose, ni mucho menos el mundo va perdiendo la diversidad (Gledhill 1999:31). Existe un proceso de localización de cultura en la globalización (García Canclini 1995:69-71). Rolando Robertson (1995) entiende este proceso de la creación de cultura con el término glocalization. En el contexto en que las "culturas" entendidas por la definición antropológica tradicional pierde sus límites con las otras y los símbolos que habían estado reunidos en cada "cultura" viajan dispersándose sin sus ancladeros, la nostalgia les da a los símbolos un nuevo marco en el que se reúnen con nueva combinación para tener una nueva forma cultural (Stewart 1988:227). Como hemos visto, bajo la fuerza de convergencia de nostalgia hegemónica, los símbolos se reubican y recombinan para "exotizar" el lugar, las personas y su cultura. Pero la forma de surgimiento de cultura local no es sólo ésta. En los procesos, en donde se materializa esta nostalgia, en los cuales los nativos de los lugares contactan con las imágenes sobre sus terruños, personas y culturas pero en formas producidas por los otros, surge la nostalgia subalterna que también glocaliza la cultura, pero con otro modo de hacer bricolaje. A través de las contiendas y las negociaciones entre ambas nostalgias, surgen distintas formas culturales. Aún podemos descubrir la diversidad cultural en los lugares construidos por las imágenes. $\mathrm{Si}$ la cultura está en incesante transformación y se crea y renueva a través de las interacciones entre los turistas y los anfitriones, podremos encontrar algo que aún no conocemos al hacer turismo.

Entre los folletos turísticos que distribuye la presidencia municipal a los visitantes y los eventos que se celebran durante las fiestas, hay tres imágenes coherentes sobre Jalostotitlán: la imagen de pueblo ranchero, la de lugar sagrado de la 
religión católica y la de las jóvenes jaleñas. En los siguientes capítulos, se analizarán los procesos de la reconstrucción del lugar y la cultura local a través de contiendas y negociaciones entre la diáspora y los nativos del lugar de origen sobre estas tres imágenes de lugar. Pero antes de hacer el análisis de estas imágenes, describiré la topografía de la comunidad jaleña transnacional, la cual servirá como mapa del viaje de esta diáspora mexicana a su lugar de origen en esta etnografía (Capítulo 2).

En el capítulo 3, se analiza cómo se forman la nostalgia de la diáspora hacia su terruño y el terruño imaginario. En primer lugar, se comparan las experiencias individuales, familiares y migratorias del sujeto con la nostalgia que describe hacia su terruño. En segundo lugar, se describe cómo los migrantes narran su terruño con los objetos que circulan entre los asentamientos y el lugar de origen. En el tercero, se analiza el papel que juegan en la formación de la nostalgia las organizaciones de los migrantes en Estados Unidos, los medios de comunicación, las políticas municipal, regional y nacional de su origen y las del Estado estadounidense. Por último, compararé la nostalgia de los migrantes jaleños con la de la segunda generación.

En el capítulo 4, se estudia cómo se realiza el proyecto de la reconstrucción del terruño. Aquí, el análisis se centra principalmente en las modificaciones de las fiestas que Jalostotitlán ha tenido desde que empezó el retorno de la diáspora en forma masiva. Pero también se describe la nostalgia de los habitantes del lugar de origen, ya que aquellas personas que siente la nostalgia hacia el terruño no sólo son los jaleños desplazados geográficamente, sino también los nativos cuando el paisaje y el modo de vida de esta comunidad local han cambiado en los procesos de la industrialización, la urbanización y la transnacionalización.

Como he dicho, en las imágenes Jalostotitlán se representa como pueblo ranchero, lugar sagrado y tierra de las jóvenes jaleñas. Sin embargo, estas tres imágenes de Jalos se contradicen con las realidades que ha vivido en las últimas décadas. En cuanto a la primera imagen, es cierto que la base económica del municipio había descansado en las actividades agropecuarias hasta la primera mitad del siglo XX, pero, desde los años cincuenta el número de campesinos, 
rancheros y trabajadores agrícolas se ha reducido constantemente, y Jalostotitlán se ha desplazado de la comunidad ranchera a la urbana e industrializada (López Cortes 1999). No obstante, en los eventos de las fiestas y las imágenes que circulan dentro de la comunidad transnacional, Jalos se representa como un pueblo de la cultura ranchera. Lo que se cuestiona en capítulo 5 es la definición de lugar: ¿Jalos es una ciudad o un pueblo?. Discutiré este punto comparando la definición administrativa con la sentimental de los jaleños. También se cuestiona la definición de "cultura ranchera". El antropólogo Andrés Fábregas (1986) describe que Jalostotitlán posee los rasgos de la cultura ranchera de Los Altos de Jalisco. A diferencia de las comunidades rancheras de otras regiones del país, las poblaciones rancheras del Occidente de México son fundamentalmente criollas, o sea, de origen peninsular con pocos rasgos indígenas. Otra característica de la cultura ranchera que él define es que los habitantes de la región alteña tienden a poseer la tierra en propiedades privadas más que en ejidos y están organizados en familias, principalmente, por tres generaciones, en las cuales la autoridad reside en el hombre o la mujer de más edad. Pero es muy distinta esta cultura ranchera antropológica de la cultura que se representa en los folletos y los eventos de las fiestas, dado que la imagen del pueblo ranchero en las fiestas, más bien, está basada en la charrería y la música Tex-Mex.

Desde que los misioneros franciscanos llegaron a la región alteña a mediados del siglo XVI, la historia local y la vida de los habitantes de Jalostotitlán habían estado ligadas estrechamente a la religión católica. Por ejemplo, como otras comunidades de esta región, esta comunidad aportó contingentes importantes para la guerra cristera, de 1927 a 1929, que fue uno de los factores principales de la primera migración masiva de los jaleños a Estados Unidos (Fábregas 1986). Las fiestas que se celebran actualmente en la temporada del retorno de los ausentes también son fiestas relacionadas con esta religión: las fiestas patronales en agosto son para Nuestra Señora de la Asunción, y el Carnaval, que se celebra cuarenta días antes de la Semana Santa, tiene origen en la primera época de evangelización. Pero, desde que inició el retorno masivo de los migrantes de Estados Unidos en las últimas décadas, acompañados con 
distintos estilos de vida, costumbres, ideas y mercancías derivados del otro lado de la frontera y otras prácticas religiosas empezaron a difundirse entre los habitantes (López Cortes 1999). Por tanto, esta imagen de lugar sagrado no necesariamente representa la diversidad de practicas religiosas de los jaleños.

En la primera parte de capítulo 6 se analiza el papel que juega la religión católica en el retorno y la reconstrucción del lugar de origen. Relacionado con este tema, este viaje turístico de la diáspora a su lugar de origen durante las fiestas se puede considerar como una peregrinación o un "viaje sagrado". ${ }^{22}$ Se observan tres funciones de este ritual: en primer lugar, ofrece tanto a los habitantes del lugar de origen como a los ausentes una ocasión de reencuentro para resolver conflictos emocionales por la causa de la separación; en segundo, por un lado, este reencuentro estimula a los habitantes a emigrar al Norte y promueve la migración, por el otro, a través de este retorno, se nutre la imagen del terruño y se alimenta el mito de retorno entre los demás miembros de la diáspora que aún no regresa a su lugar de origen, y por último, este ritual les da tanto a los presentes como los ausentes el sentido de pertenencia a la comunidad local y el imaginario colectivo y produce el sentido de ser jaleño. Pero este último aspecto del ritual se analiza en términos de poder. Como Andrea Louie (2000) analiza el festival juvenil para los jóvenes miembros de la diáspora china, el ritual funciona como un aparato ideológico pero no necesariamente logra una identidad homogénea entre los sujetos que viven diferentes experiencias dentro de la comunidad transnacional.

En el capítulo 7 estudiaré la nostalgia de la diáspora y la imagen de Jalos en términos de género. Hay una imagen o estereotipo difundido entre los visitantes masculinos: las janeñas son "güeras" con ojos claros y son "tradicionales", religiosas y fieles a los hombres y además, son solteras que están interesadas en el matrimonio debido a la escasa población masculina por el alto índice de la migración. De hecho, el municipio responde a esta "necesidad" de los visitantes en la forma en que se organizan algunos eventos, tales como el Certamen de la Señorita Jalos, la serenata, que es una ceremonia tradicional que se practica en la

\footnotetext{
${ }^{22}$ Véase Nelson Graburn, 1977, "Tourism: The Sacred Journey, en Smith (ed.), Host and Guest: The Anthropology of Tourism. Philadelphia: The University of Pennsylvania Press.
} 
plaza de la cabecera municipal entre jóvenes solteros para buscar la pareja, para ver y conocer a las jaleñas y se usan las imágenes de mujer jaleña al promover la visita a Jalostotitlán a traves del Internet y los folletos. No obstante, las jóvenes jaleñas no son una categoría homogénea. En los procesos de la transnacionalización de sus vidas, las experiencias de ser jaleña se han diversificado. Aparte de las jaleñas que definen la identidad de género en términos de abnegación y labor doméstica, también hay mujeres que se identifican como trabajadoras y desean ser independientes. Tampoco ser jaleña significa solamente ser mujer que siempre ha vivido en Jalostotitlán, Los Altos de Jalisco, en el contexto en que los habitantes de otras localidades en otro país, que forman parte de la comunidad transnacional, también se identifican como jaleños. Hay jaleñas nacidas o crecidas en Estados Unidos cuya identidad de género no necesariamente coincide con la imagen de mujer tradicional en el lugar de origen.

Al cerrar esta etnografía, en capítulo 8, discutiré sobre la reconstrucción del terruño, la cultura local e identidad y la comunidad transnacional que se está constituyendo a través de este retorno. 


\section{Bibliografía}

Anderson, Benedict

1983 Imagined Communities: Reflections on the Origin and Spread of Nationalism. Londres: Verso.

1992 "The New World Disorder", en New Left Review 193:3-13.

Appadurai, Arjun

1988 "Intruduction: Place and Voice in Anthropological Theory" en Cultural Anthropology, 3 (1):16-20.

1991 La vida social de las cosas: perspectiva cultural de las mercancías. México: Grijalbo.

Augé, Marc

1998a La guerra de los sueños: Ejercicios de etno-ficción, Barcelona: Gedisa. 1998b El viaje imposible: El turismo y sus imágenes, Barcelona: Gedisa.

Banco de México 2002 Informe Anual 2001, abril, 2002.

Basch, Linda, Glick Schiller, Nina y Szanton Blanc, Cristina

1994 Nations Unbound: Transnational Projects, Postcolonial and Deterritorialized Nation States. Amsterdam: School of American Research.

Baudrillard, Jean

1978 "La precesión de los simulacros", en Cultura y Simulacro, Barcelona: Editorial Kairós.

Besserer, Federico

1999 "Estudios transnacionales y ciudadanía transnacional", en Gail Mummert (ed.), Fronteras Fragmentadas. México: El Colegio de Michoacán y Centro de Investigación y Desarrollo del Estado del Michoacán, pp.215238.

Boorstin, Daniel

1964 The image: A Guide to pseudo-events in America. Nueva York: Harper y Row Publishes.

Boruchoff, Judith

1999 "Equipaje cultural: Objetos, Identidad y Transnacionalismo en Guerrero y Chicago", Gail Mummert (ed.) Fronteras Fragmentadas. México: El Colegio de Michoacán, Desarrollo del Estado de Michoacán, pp.499518.

Bruner, Edward

1989 "Of Cannibals, Tourists, and Ethnographers", Cultural Anthropology, 1989. 4(4), pp. 438-445.

1996 "Tourism in Ghana: The Representation of Slavery and the Return of the Black Diaspora", American Anthropologist, 1996, 98(2):290-304.

Castaneda, Quetzil

1995 'La economía 'escritural' y la invención de las culturas maya en el 'museo' de Chichen Itza”, en Revista Española de Antropología Americana 25. 
1996 In the Museum of Maya Culture: Touring Chichen Itza. Minneapolis: University of Minnesota Press.

Clifford, James

1988 The Predicament of Culture: Twentieth-Century Ethnography, Literature, and Art. Cambridge, MA: Harvard University Press.

1999 Itinerarios Transculturales. Barcelona: Gedisa.

Chow, Rei

1993 "What have all the native gone?", en Writing Diaspora: Tactics of Intervention in Contemporary Cultural Studies. Bloomington y Indianapolis: Indiana University Press.

Durand, Jorge

1994 Más allá de la línea. Patrones migratorios entre México y Estados Unidos. México: Conaculta.

Ebron, Paulla A.

2000 "Tourists as pilgrims: commercial fashioning of transatlantic politics", American Ethnologist, 2000, 25(4):910-932.

Eco, Umberto

1999 "Viaje a la Hiperrealidad", La estrategia de la ilusión, Barcelona: Lumen.

Espinosa, Víctor $\mathrm{M}$.

1999 "El día del emigrante y el retorno del purgatorio: Iglesia, migración a Estados Unidos y cambio sociocultural en un pueblo de los Altos de Jalisco", Estudios Sociológicos XVII: 50: 375-418.

Fábregas, Andrés

1986 La formación histórica de una región: Los Altos de Jalisco. México: Ediciones de la Casa Chata (Colección Miguel Othón de Mendizabal, No. 5.

Foucault, Michel

1982 "The Subject and Power" en Michel Foucault: Beyond Structuralism and Hermeneutics. Hubert Dreyfus and Paul Rabinow (eds.), pp.208-226.

Chicago: University of Chicago Press.

García Canclini, Néstor

1989 Culturas Híbridas: Estrategias para entrar y salir de la modernidad, México: Grijalbo.

1995 Consumidores y Ciudadanos: Conflictos multiculturales de la globalización, México: Grijalbo.

Gledhill, John

1999 "El reto de la globalización: Reconstrucción de identidades, formas de vida transnacionales y las ciencias sociales", Gail Mummert (ed.), Fronteras Fragmentadas. México: El Colegio de Michoacán, Desarrollo del Estado de Michoacán, pp.23-55.

Glick Schiller, Nina, Basch, Linda y Blanc-Szanton, Cristine 1992a "Transnationalism: A New Analitic Framework for Understanding Migration", Glick Schiller, Nina, Basch, Linda y Blanc-Szanton, Cristine (eds.), Towards a transnational Perspective on Migration:Race, Class, Ethnicity and Nationalism Reconsidered. New York: Annuals of the New York Academy of Science Vol.645.June: 1-24. 
1992b "Transnational Projects of Immigrants and Ethnographers, and the Cultural Politics of Nation States", Ponencia presentada en la reunión de la AAA en Dieciembre de 1992 en San Francisco.

Goldring, Luin

1997 "Difuminando fronteras: Construcción de la comunidad transnacional en el proceso migratorio México-Estados Unidos", en Migración laboral internacional: Transnacionalidad del espacio social. Saúl Macías Gamboa y Fernando Herrera Lima (Coordinadores). México: Universidad Autónoma de Puebla.

González de la Rocha, Mercedes y Escobar Latapí, Agustín

1990 "La ley y la migración internacional: el impacto de la 'Simpson- Rodino' en una comunidad de los Altos de Jalisco", Estudios Sociológicos VIII: 24, 1990, pp.517-546.

González Gutiérrez, Carlos

1999 "Promoviendo identidades: Las relaciones del Estado mexicano con las comunidades de origen mexicano en los Estados Unidos", Gail Mummert (ed.), Fronteras Fragmentadas. México: El Colegio de Graburn, Nelson Michoacán, Desarrollo del Estado de Michoacán, pp.271-296.

1977 "Tourism: The Sacred Journey, en Smith (ed.), Hosts and Guests: The Anthropology of Tourism. Philadelphia: The University of Pennsylvania Press.

Greenwood, Davydd J.

1977 "Culture by the Pound: An Anthropological Perspective on Tourism as Cultural Commoditization", Smith (ed.), Hosts and Guests: The Anthropology of Tourism. Philadelphia: The University of Pennsylvania Press.

Gupta, Akhil y Ferguson, James

1999 "Beyond 'Culture': Space, Identity, and Politics of Difference", en Akhil Gupta y James Ferguson (eds.), Culture, Power, Place. Explorations in Cultural Anthropology, Durham: Duke University Press, pp.33-51.

Gutiérrez R., Alfredo

2000 Xalostotitlán en Imágenes. Guadalajara: Acento Editores y Editorial amate.

Hall, Stuart

1990 "Cultural Identity and Diaspora", Jonethan Rutherford (ed,), Identity: Community, Cultural Difference. London: Lawrence and Wishart.

Hirai, Shinji

2002 "Viajes al terruño imaginario: El estado post-nacional y el turismo mexicanos", ponencia presentada el el coloquio internacional de "Transnacionalidad: Una mirada etnográfica y multidisciplinaria", en el 11-12 de marzo de 2002 en la Ciudad de México.

Hobsbawm, Eric y Ranger, Terrence (eds.)

1983 The Invention of Tradition. Cambridge: Cambridge University Press.

Instituto Nacional de Estadística, Geografía e Informática (INEGI) 
2001 Tabulados Básicos Nacionales y por Entidad Federativa. Base de Datos y Tabulados de la Muestra Censal, XII Censo General de Población y Vivienda, 2000. México.

Ishikawa, Noboru

1993 "Noumin to Oufukukippu: Jyunkan roudou imin to Community kenkyu no gensen", en The Japanease Journal of Ethnology. 1993, 58(1): 53-71.

Jameson, Fredric

1984 "Posmodernism, or the Cultural Logic of Late Capitalism" en New Left Review.146: 53-92.

Kearney, Michael

1991 "Borders and Boundaries of State and Self at the End of the Empire". Journal of Historical Sociology. 4(1): 52-74.

1992 "Beyond the Limites of the Nation-State: Popular Organizations of Transnational Mixtec and Zapotec Migrants", ponencia presentada en la reunión de la AAA en Diciembre de 1992 en San Francisco.

Kuper, Adam

2000 Culture: The Anthropologists' Account, Cambridge: Harvard University Press.

López Ángel, Gustavo y Thoric Nils Cedestrom

1991 "Moradores en el purgatorio: el regreso periódico de los migrantes como una forma de peregrinación", en Memoria del Simposio Internacional de Investigadores Regionales, Puebla: INAH.

López Cortés, Eliceo

1999 Último cielo en la cruz: Cambio sociocultural y estructuras de poder en Los Altos de Jalisco. Jalisco: SEMS y El Colegio de Jalisco.

Louie, Andrea

2000 "Re-territorializing transnationalism: Chinese American and the Chinese motherland", American Ethnologist. 2000, 27(3):645-669.

Lozano Ascencio, Fernando

1998 "Continuidad y cambios en la migración entre México y Estados Unidos", Manuel Angel Castillo, Alfredo Lattes y Jorge Santibañez (eds.), Migración y Fronteras. México: El Colegio de la Frontera Norte, El Colegio de México, Asociación Latinoamericano de Sciología.

Lutkehaus, Nancy Christine

1989 "'EXCUSE ME, EVERYTHING IS NOT ALL RIGHT': On Ethnography, Film, and Representation", Cultural Anthropology,1989. 4(4):422-437.

MacCannell, Dean

1973 "Staged Authenticity: Arrangements of Social Space in Tourist Settings", en American Journal of Sociology 79:589-603.

Maeyama, Takashi

1994 "Postcolonialism and Cultural anthropology", en Annual of Social Anthropology. 20: 1-25.

Mason, Peter

1998 Infelicities: Representations of The Exotic, Baltimore: John Hopkins University Press.

Marcus, George E. 
1998 "Ethnography in/of the World System. The Emergence of multi-sited ethnography", en Ethnography through Thick and Thin. Princeton: Princeton University Press.

Marcus, George E. y Fischer, Michael MJ.

1986 Anthropology as cultural critique: An Experimental moment in the Human Sciences, Chicago: The University of Chicago Press.

Montes García, Olga

1992 "La migración en la Sierra Norte: sus cambios culturales", en Migración y Etnicidad en Oaxaca. Nashville, Tennessee: Universidad de Vanderbilt.

Morrison, Toni

1990 "The Site of Memory", en Out There: Marginalization and Contemporary Cultures. Russell Ferguson, Martha Gever, Trinh T. Minh-ha y Cornel West (eds.), Cambridge, MA: MIT Press, pp. 299-305.

Narita, Tokuhira et.al. (eds)

1985 Kindaika no nakano Ainu sabetu no Kouzou. Tokio. Akashisyoten.

Ota, Yoshinobu

1993 "Objectification of Culture: The Creation of Culture and Identity in the Tourist World", The Japanease Journal of Ethnology. 1993, 57(4): 383410.

Pratt, Mary Louise

1992 Imperial Eyes: Travel Writing and Transculturation. Londres: Routledge.

Redfield, Robert

1941 The Folk Culture of Yucatan. Chicago: University of Chicago Press.

1950 A Villege That Chose Progress: Chan Kom Revisited. Chicago: University of Chicago Press.

Robertson, Jennifer

1991 Native and Newcomer: Making and Remakeing a Japanese City. Berkley: University of California Press.

Robertson, Roland

1995 "Glocalization: Time-Space and Homogeneity-Heterogeneity", S. Lash y R. Robertson (eds.), Global Modernities, Londres: Sage Publications, pp. 25-44.

Rosaldo, Renato

1989 Culture and Truthe: The Remaking of Social Analysis. Boston: Beacon Press.

Rouse, Roger

1988 Mexican Migration to the United States: Famuly Relations on the Development of a Transnational Migrant Circuit. Tesis doctoral. Stanford: Department of Anthropology, University of Stanford.

1991 "Mexican Migration and the Social Space of Postmodernism", en Diaspora, 1(1): 8-23.

Rushdie, Salman

1991 "Imaginary Homelands", Jay O'Brien y William Rosberry (eds.), Golden ages, dark ages: Imagining the past in Anthropology and History. Berkley: University of California Press. 
Safran, William

1991 "Diaspora in Modern Societies: Myths of Homeland and Return", Diaspora Spring. 1991:83-99.

Smith, Valenne L. (ed.)

1977 Hosts and Guests: The Anthropology of Tourism. Philadelphia: The University of Pennsylvania Press.

Stewart, Kathleen

1988 "Nostalgia-A Polemic", Cultural Anthropology. 1988 3(3):227-241.

Wai-Teng Leong

1989 "Culture and the State: Manufacturing traditions for Tourism", Critical Studies in Mass Communication 6(1989):355-375.

Williams, Raymond

1973 The Country and The City. Newyork: Oxford University Press.

Yamashita, Shinji

1995 ''Rakuen' no Souzou: Bali niokeru Kankou to Dentou no

Saikouchiku". Yamashita, Shinji (ed.) Kankou Jinruigaku. Tokio: Shinyousya. 